\title{
Prognostic factors for persistent pain after a first episode of nonspecific idiopathic, non-traumatic neck pain
}

\author{
Citation for published version (APA):
}

Verwoerd, M., Wittink, H., Maissan, F., de Raaij, E., \& Smeets, R. J. E. M. (2019). Prognostic factors for persistent pain after a first episode of nonspecific idiopathic, non-traumatic neck pain: A systematic review. Musculoskeletal science and practice, 42, 13-37. https://doi.org/10.1016/j.msksp.2019.03.009

Document status and date:

Published: 01/07/2019

DOI:

10.1016/j.msksp.2019.03.009

Document Version:

Publisher's PDF, also known as Version of record

\section{Document license:}

Taverne

Please check the document version of this publication:

- A submitted manuscript is the version of the article upon submission and before peer-review. There can be important differences between the submitted version and the official published version of record.

People interested in the research are advised to contact the author for the final version of the publication, or visit the DOI to the publisher's website.

- The final author version and the galley proof are versions of the publication after peer review.

- The final published version features the final layout of the paper including the volume, issue and page numbers.

Link to publication

\footnotetext{
General rights rights.

- You may freely distribute the URL identifying the publication in the public portal. please follow below link for the End User Agreement:

www.umlib.nl/taverne-license

Take down policy

If you believe that this document breaches copyright please contact us at:

repository@maastrichtuniversity.nl

providing details and we will investigate your claim.
}

Copyright and moral rights for the publications made accessible in the public portal are retained by the authors and/or other copyright owners and it is a condition of accessing publications that users recognise and abide by the legal requirements associated with these

- Users may download and print one copy of any publication from the public portal for the purpose of private study or research.

- You may not further distribute the material or use it for any profit-making activity or commercial gain

If the publication is distributed under the terms of Article $25 \mathrm{fa}$ of the Dutch Copyright Act, indicated by the "Taverne" license above, 
Systematic Review

\title{
Prognostic factors for persistent pain after a first episode of nonspecific idiopathic, non-traumatic neck pain: A systematic review
}

\author{
Martine Verwoerd $^{\mathrm{a}, *}$, Harriet Wittink ${ }^{\mathrm{a}}$, Francois Maissan ${ }^{\mathrm{a}}$, Edwin de Raaij ${ }^{\mathrm{a}}$, Rob J.E.M. Smeets ${ }^{\mathrm{b}}$ \\ ${ }^{\text {a }}$ Research Group Lifestyle and Health, Utrecht University of Applied Sciences, Heidelberglaan 7, Utrecht, the Netherlands \\ ${ }^{\mathrm{b}}$ Department of Rehabilitation Medicine, Research School CAPHRI, Maastricht University; CIR Rehabilitation, Eindhoven, The Netherlands
}

\section{A R T I C L E I N F O}

\section{Keywords:}

Chronic neck pain

Idiopathic neck pain

Prognostic factors

Systematic review

\begin{abstract}
A B S T R A C T
Background: Prognosis of acute idiopathic neck pain is poor. An overview of modifiable and non-modifiable prognostic factors for the development of chronic musculoskeletal neck pain after an episode of idiopathic, nontraumatic neck pain is needed.

Objective: Identify prognostic factors for pain intensity and perceived non-recovery at three, six and 12 months after a first episode of idiopathic, non-traumatic neck pain.

Study design: Systematic review

Methods: Systematic literature search up to October 21, 2017 for prospective prognostic studies with main outcomes perceived non-recovery and pain intensity. The QUIPS was used for quality assessment.

Results: Out of 2737 screened articles six prospective studies with high-risk-of-bias were identified, analyzing 47 and 43 factors for the outcome variables 'pain intensity' and 'perceived non-recovery', respectively. Based on univariate- and multivariate analyses we found moderate evidence for 'age $>40$ years' and 'concomitant back pain' to be prognostic for 'pain intensity'. For the outcome 'perceived non-recovery' at 12 months, we found moderate evidence for both 'a previous period of neck pain' and 'accompanying headache' as prognostic variables for persistent pain, based on univariate analysis. No prognostic factor was found which was retained in more than one multivariate analysis for the outcome variable 'perceived non-recovery'. However, the quality of the evidence for these prognostic factors was low to very low.

Conclusion: This review identifies prognostic factors for neck pain, of which only a few are modifiable. Further research is needed before drawing definite conclusions about the prognostic value of these factors.
\end{abstract}

\section{Introduction}

Musculoskeletal (MSK) conditions pose an enormous burden on individuals, health systems, and social care systems, and are dramatically increasing in developing countries, particularly due to rapidly ageing populations and increasing obesity (Hoy et al., 2014). Trends of non-fatal diseases show that neck pain is third in the rating of 'years lived with disability' in Europe (GBD, 2016). The incidence of neck pain in the general population is estimated between 15 and $18 \%$ per year (Côté et al., 2004; Croft et al., 2001). In 2016, the prevalence was 20.8 per 1000 patient years in general practitioner practices in the Netherlands. (Koppes, 2016).

Most episodes of acute neck pain are thought to resolve with or without treatment. However, Hush et al. found Level 1 evidence that the prognosis of acute idiopathic neck pain is worse than currently recognized (Hush et al., 2011). Childs et al. (2008) suggest that rates of persistent neck pain are substantial: $30 \%$ of patients with neck pain will develop chronic symptoms (Bovim et al., 1994), and 37\% of individuals who experience neck pain will report persistent problems for at least 12 months (Côté et al., 2004).

Chronic pain negatively affects patient perception of general health, interferes considerably with everyday activities as a function of pain severity, is associated with depressive symptoms, and dramatically and negatively affects relationships and interactions with others (Reid et al., 2011). Studies report that the effect of physiotherapy treatment after the occurrence of chronic musculoskeletal pain is at best only moderate (Geneen et al., 2017; Bertozzi et al., 2013; Gross et al., 2015). It is therefore essential to prevent chronic pain and ensuing disability in the first place. Knowledge of the clinical course of neck pain and prognostic potentially modifiable and non-modifiable prognostic variables help health care providers to improve clinical decision-making and to manage expectations of people with neck pain. Prognostic factors are

\footnotetext{
* Corresponding author.

E-mail address: martine.verwoerd@hu.nl (M. Verwoerd).
} 
defined as characteristics that are associated with clinical outcomes in patients with a given health condition (Riley et al., 2013), whereas predictive factors are defined as characteristics that identify subgroups of treated patients having different outcomes (Adolfsson and Steineck, 2000). Before clinical characteristics can be used to justify specific treatments, it is imperative that the prognostic effects of these characteristics are distinguished from their ability to predict a differential clinical benefit from a specific treatment (Clark, 2008). Previous research has often used these terms imprecisely (Wingbermühle et al., 2018; Kelly et al., 2017). Prior systematic reviews on prognostic factors in nonspecific neck pain have included a majority of studies on patients with whiplash-associated disorder (WAD) (Wingbermühle et al., 2018; Walton, 2013; Kelly et al., 2017). The findings of these reviews cannot be generalized to patients with idiopathic nonspecific, non-traumatic, acute- or subacute neck pain because patients with WAD are different in muscle function, cervical pressure pain thresholds, self-reported and patient-specific function, depression, active range of motion, pain intensity and disability in the chronic phase and have different beliefs with regard to recovery (Stenneberg et al., 2017; Anstey et al., 2016; Ris et al., 2017). Only one study was found that reported comparable improvement in and prognostic factors for pain, function and recovery between patients with WAD and patients with nonspecific neck pain (Verhagen et al., 2011).

Consequently, we think it is essential to analyze the group of nonspecific, acute- and subacute neck pain patients separately. Even though Hush et al. did analyze the prognosis of acute idiopathic neck pain, they did not analyze the prognostic factors (Hush et al., 2011). To the best of our knowledge, prognostic factors in this subgroup have not yet been reviewed systematically.

Chronicity has been variously described in three core domains 'persisting symptoms', 'disability' and 'work status' (Pincus et al., 2002). As our primary interest is the prevention of chronic pain, we chose 'pain intensity' and 'perceived non-recovery' as our outcome variables. This is also in line with the IMPACT recommendations and different observational studies and systematic reviews on chronification of musculoskeletal pain (Gewandter et al., 2015; Pierik et al., 2015; Bérubé et al., 2017; Traeger et al., 2016; Struyf et al., 2016). Besides, in clinical practice patients most often report pain as the most important problem and their treatment aim is to reduce (Sanderson et al., 2010; Casarett et al., 2001; Bromley Milton et al., 2013).

The purpose of this study is to identify and synthesize the evidence regarding modifiable and non-modifiable prognostic factors for the development of chronic musculoskeletal neck pain after a first episode of idiopathic, non-traumatic neck pain, operationalized by the outcome variables 'pain intensity' and 'perceived non-recovery'.

\section{Methods}

\subsection{Protocol and registration}

We registered the review protocol in the international prospective register of systematic reviews (Prospero) database with registration number CRD42016050346 in October 2016. At that time, there was no other similar review protocol registered on this topic.

This review is written in accordance with Preferred Reporting Items for Systematic Reviews and Meta-Analyses (PRISMA) guidelines (Moher et al., 2009).

\subsection{Search}

Potentially relevant studies were identified through systematic searches in the following electronic databases: Medline (PubMed), PsycINFO, EMBASE, SPORTdiscus and CINAHL. The databases were searched from inception up to October 21, 2017.

A comprehensive search strategy was developed in consultation with a medical information specialist. The search strategy consisted of three major elements: (1) chronification; (2) neck pain; and (3) prognostic factors.

For each element, we collected all known synonyms and related terms to extract the maximum number of articles from the databases. To ensure sufficient precision, the key terms were mapped to medical subject headings $(\mathrm{MeSH})$, and title and abstract search words and phrases were added.

We build the search string for PubMed and then translated it into a syntax for the other databases. All databases were individually searched. We imported all references into RefWorks and excluded duplicate articles. Furthermore, to ensure a maximum number of eligible studies, we scanned the reference lists of all included articles.

The complete search strategy can be found in Appendix 1. The translations of the search string to all databases are available on request from the first author.

As a supplement to the systematic search, we also searched the grey literature.

For grey literature we used the following electronic sources up to October 21, 2017: DART-Europe E-theses Portal, Open Access Theses and Dissertations, Networked Digital Library of Theses and Dissertations (NDLTD), ClinicalTrials.gov and WHO International Clinical Trials Registry Platform (ICTRP).

\subsection{Eligibility criteria}

Table 1 provides an overview of the in- and exclusion criteria. As we specifically focused on musculoskeletal idiopathic, non-traumatic neck pain, we defined musculoskeletal pain as pain that arises as part of a disease process directly affecting bone(s), joint(s), muscle(s), or related soft tissue(s) (Treede et al., 2015). Idiopathic, non-traumatic neck pain was defined as neck pain of unknown origin (Hush et al., 2011). We included only studies with a follow-up period of at least 3 months in univariate or multivariate analysis, because chronic pain is defined as pain that persists longer than 3 months or is recurring (Treede et al., 2015). We specifically excluded studies that reported predictive factors for a specific treatment.

Table 1

Study selection criteria.

\begin{tabular}{|c|c|}
\hline Inclusion & Exclusion \\
\hline Prospective cohort studies & $\begin{array}{l}\text { Neck surgery, Radiculopathy and Myelopathy, Headache, wide spread } \\
\text { pain, no neck pain at baseline }\end{array}$ \\
\hline Univariate to identify prognostic factors & $\begin{array}{l}\text { Pain not due to musculoskeletal pain (affecting bone(s), joint(s), } \\
\text { muscle(s), or related soft tissue(s)) }\end{array}$ \\
\hline $\begin{array}{l}\text { Human adults ( } 18 \text { years or older) formed at least } 60 \% \text { of the sample }{ }^{\mathrm{a}} \text {, had to have idiopathic, non- } \\
\text { traumatic acute- ( } 0-3 \text { weeks) and/or sub-acute ( } 3-12 \text { weeks) neck pain }\end{array}$ & $>40 \%$ of the sample has whiplash related neck pain ${ }^{\mathrm{a}}$ \\
\hline \multicolumn{2}{|l|}{ Follow-up period at least 3 months } \\
\hline \multicolumn{2}{|l|}{ Published in English, Dutch, French or German } \\
\hline Outcomes pain or perceived non-recovery & \\
\hline
\end{tabular}

\footnotetext{
${ }^{a}$ A threshold of $60 \%$ was randomly chosen for pragmatic reasons to not overlook potentially useful prognostic factors.
} 


\subsection{Study selection}

Screening was done by two reviewers (MV and HW) in a two-step procedure. During the first step, the two reviewers independently screened all articles for eligibility based on their title and abstract. During the second step, the same reviewers independently performed a review of the full text articles that were included after the first step. If consensus could not be reached, a third reviewer (FM) made the final decision.

Our final set of studies consisted of all papers for which both reviewers independently decided that they met the inclusion criteria. All disagreements were resolved by discussion.

\subsection{Data extraction}

Two reviewers (MV and HW) independently extracted data from each included study. An extraction manual was designed to facilitate the data collection process. In addition, the reviewers performed a test session to calibrate the extraction process. The following information was collected:

a) study article (authors, publication date, country), b) study design and statistical methods, c) characteristics of the study population, d) baseline prognostic factors, e) primary outcome measurements; i.e. pain intensity, patient perceived non-recovery, f) time to follow-up, number of patients at follow-up, g) statistical analyses, h) \% patients recovered and i) quality of the study.

\subsection{Risk of bias in individual studies}

Risk of bias (RoB) was assessed by two independent reviewers (MV and HW) using the Quality In Prognostic Studies (QUIPS) tool. The QUIPS is a six-item, useful and reliable tool to guide comprehensive assessment of six bias domains in studies of prognostic factors (Hayden et al., 2013). The six domains are study participation, attrition, prognostic factor measurement, outcome measurement, study confounding, and statistical analysis and reporting. The six domains are rated as high, moderate or low RoB. Prior to assessing bias of the included studies, the QUIPS was tested on several non-included studies for calibration purposes. For overall RoB of individual studies, recommendations by Hayden et al. (2013) were followed, in which a study was considered to be at low RoB when each of the six bias domains was rated as having low RoB. Studies that scored moderate or high RoB on at least one domain were rated as high RoB (Hayden et al., 2013).

\subsection{Synthesis or results}

A prognostic factor was defined as a variable that was significantly associated with the main outcomes 'pain intensity' or 'perceived nonrecovery'. A significant association was defined as a univariate or multivariate association, or an association adjusted for confounding or other prognostic variables, with a $\mathrm{p}$ value $<0.05$, or an Odds Ratio (OR) or Relative Risk with a $\geq 90 \% \mathrm{CI}$ not including one (Artus et al., 2017). To be consistent in the direction of the association we calculated the inverse of the Odds Ratios (OR) to determine the OR for non-recovery as four studies used good recovery as their main outcome (Pool et al., 2010; Hoving et al., 2004; Wirth et al., 2016; Vos et al., 2008) and two studies used poor recovery as their main outcome (Schellingerhout et al., 2010; Hill et al., 2004).

Meta-analysis was not performed as the included studies were dissimilar with respect to patient population and outcome(s). Therefore, a qualitative data synthesis was performed according to Hayden et al., 2013, 2014 taking into account the strength and consistency of results (Table 2). Following Hayden et al., 2013, 2014, a prognostic factor is considered to be of 'limited evidence' if it was researched in only one study. A prognostic factor is considered to be of 'moderate evidence' if more than one high risk of bias study and/or one low risk of bias study provide consistent evidence ( $>75 \%$ of the studies showing the same direction of effect). 'Strong evidence' is given if more than one low risk of bias study provide consistent evidence.

Two independent reviewers (MV and HW) used a modified GRADE approach (Huguet et al., 2013) to judge the overall quality of evidence of all included studies. The approach classifies evidence into high, moderate, low, or very low quality (see Table 3), whereby six study characteristics downgrade the quality of evidence (phase of investigation, study limitation, inconsistency, indirectness, imprecision, publication bias), and two study characteristics upgrade the quality of evidence (moderate or large effect size, exposure-response gradient).

\section{Results}

\subsection{Study selection}

The review selection process is outlined in Fig. 1. The search strategy resulted in 2737 articles after removing 1692 duplicates. After screening titles and abstracts we included 25 articles for detailed fulltext screening (see Appendix 3). The inspection of all reference lists of these 25 articles and the systematic reviews in our orientation phase resulted in one additional study for detailed screening. The search in the grey literature resulted in 283 full text articles, none of which met our eligibility criteria.

After the detailed full-text screening procedure, our final sample consisted of six articles. Most articles were excluded as they (1) not only analyzed acute- and/or sub-acute idiopathic neck pain patients, but also $>40 \%$ traumatic- or chronic neck pain patients, or (2) the study did not differentiate between neck pain and other musculoskeletal pain, or (3) the study included healthy participants at baseline. All disagreements were resolved by consensus.

\subsection{Study characteristics}

The characteristics of the six included studies are presented in Appendix 2. The six studies (Pool et al., 2010; Hoving et al., 2004; Wirth et al., 2016; Vos et al., 2008; Schellingerhout et al., 2010; Hill et al., 2004) were conducted in the Netherlands (four studies) (Pool et al., 2010; Hoving et al., 2004; Vos et al., 2008; Schellingerhout et al., 2010), in the UK (one study) (Hill et al., 2004) and in Switzerland (one study) (Wirth et al., 2016), and analyzed prognostic factors in 2446 patients with acute- and sub-acute neck pain of which 1497 (61\%) were female and 949 (39\%) male.

Of the six studies, four were prospective cohort studies (Hoving et al., 2004; Wirth et al., 2016; Vos et al., 2008; Hill et al., 2004) and two studies (Pool et al., 2010; Schellingerhout et al., 2010) reanalyzed data from randomized controlled (RCTs) trials. One study (Schellingerhout et al., 2010) included six months follow-up data from two RCTs (Pool et al., 2010; Hoving et al., 2004) that were also separately included in this review. As the original RCTs did not report on these data, this study was retained.

Four studies recruited patients from general primary care practices (Pool et al., 2010; Hoving et al., 2004; Vos et al., 2008; Schellingerhout et al., 2010), one study from chiropractic practices (Wirth et al., 2016) and one from the general population (Hill et al., 2004).

Three (Pool et al., 2010; Hoving et al., 2004; Hill et al., 2004) out of the six studies focused on pain intensity, and five (Pool et al., 2010; Hoving et al., 2004; Wirth et al., 2016; Vos et al., 2008; Schellingerhout et al., 2010) studies on self-perceived non-recovery as the dependent variable. The follow-up periods varied across the included studies. In the three studies that used pain as their main outcome, the follow-up period was three months (Pool et al., 2010) and one year (Hoving et al., 2004; Hill et al., 2004), respectively. Of these three studies, two studies (Pool et al., 2010; Hoving et al., 2004) used a NRS pain score (0-10), and in one study (Hill et al., 2004) the patients were asked whether they had had any ache or pain, which lasted for one day or more (yes/ 
Table 2

Data synthesis (Hayden et al., 2013, 2014).

\begin{tabular}{ll}
\hline Strong evidence & Consistent findings (defined as $>75 \%$ of studies showing the same direction of effect) in multiple low risk of bias studies \\
\hline $\begin{array}{l}\text { Moderate evidence } \\
\text { Limited evidence }\end{array}$ & Consistent findings in multiple high risk of bias and/or one study with low risk of bias \\
Conflicting evidence & One study available \\
No evidence & Inconsistent findings across studies \\
& No association between variables \\
\hline
\end{tabular}

Table 3

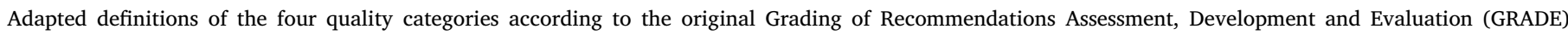
(Balshem et al., 2011), applicable to the modified GRADE (Huguet et al., 2013).

\begin{tabular}{|c|c|}
\hline High Quality & High confidence that the true effect lies close to that of the estimate of the effect \\
\hline Moderate Quality & $\begin{array}{l}\text { Moderate confidence in the effect estimate: the true effect is likely to be close to the estimate of the effect, but there is a possibility that it is substantially } \\
\text { different }\end{array}$ \\
\hline Low Quality & Limited confidence in the effect estimate: the true effect may be substantially different from the estimate of the effect \\
\hline Very Low Quality & Very little confidence in the effect estimate: the true effect is likely to be substantially different from the estimate of effect \\
\hline
\end{tabular}

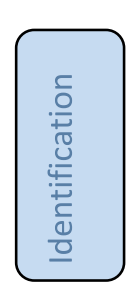

\begin{tabular}{|c|c|}
\hline \multicolumn{2}{|c|}{ Records identified through database searching } \\
\hline Database (interface) & Records \\
\hline Medline (PubMed) & 1218 \\
\hline CINAHL (EBSCO) & 865 \\
\hline PsycINFO (OVID) & 198 \\
\hline Embase (Elsevier) & 1914 \\
\hline SPORTDiscus(elsevier) & 234 \\
\hline Total & $(n=4429)$ \\
\hline
\end{tabular}
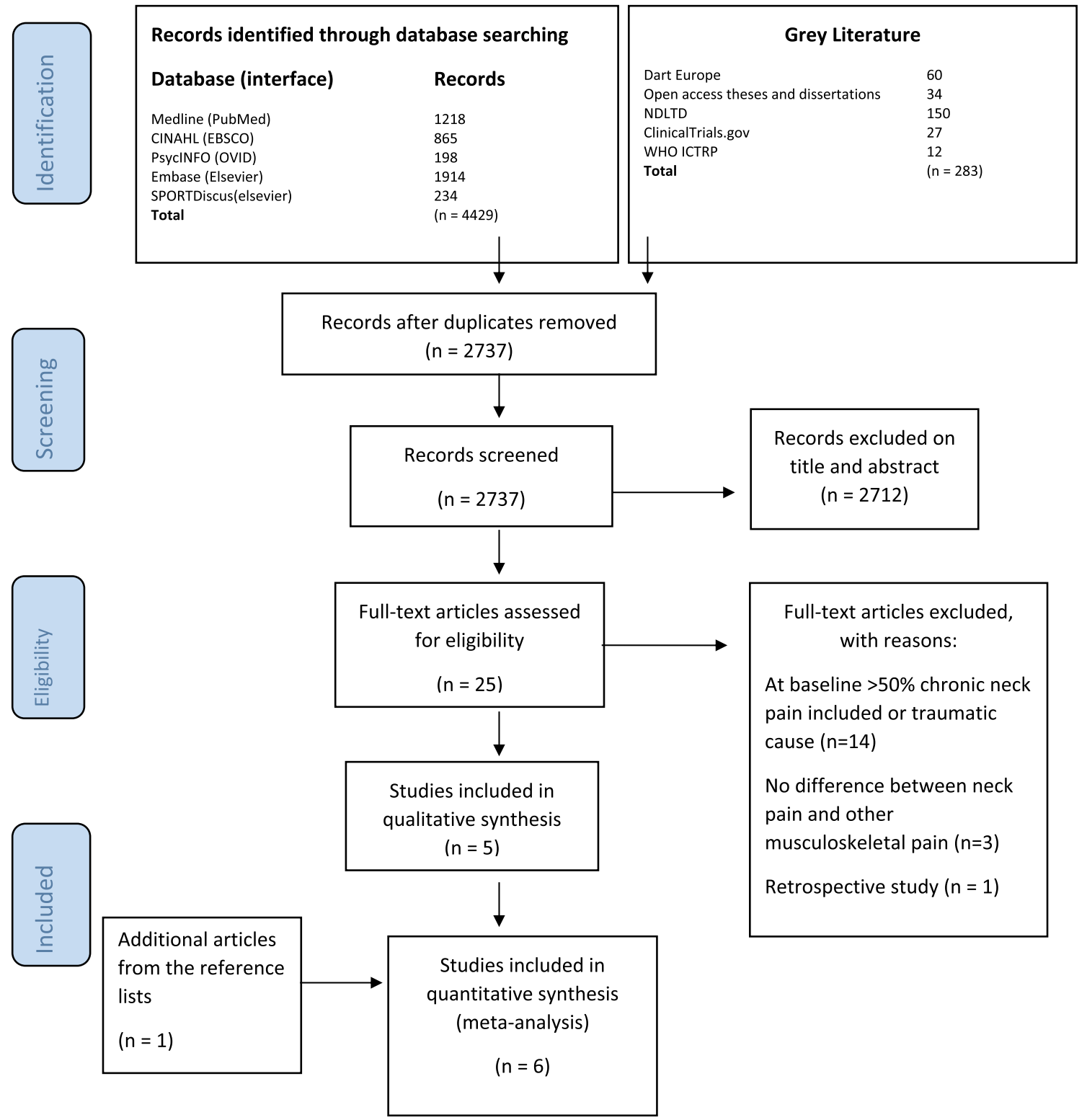
Records excluded on
title and abstract
$(n=2712)$

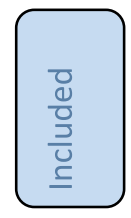

Fig. 1. PRISMA 2009 flow diagram. 
no).

In the studies that used perceived non-recovery as their main outcome, two studies had a follow-up period of three months (Pool et al., 2010; Wirth et al., 2016), one study of six months (Schellingerhout et al., 2010), and two studies of one year (Hoving et al., 2004; Vos et al., 2008). Out of the five studies that measured self-perceived non-recovery, three studies used a 7-point Likert scale (Pool et al., 2010; Wirth et al., 2016; Vos et al., 2008), one study a 6-point Likert scale (Hoving et al., 2004), and one study combined the 6- and 7-point scales (Schellingerhout et al., 2010). All scales ranged from 'completely recovered' or 'much improved' to 'worse than ever'. Hoving et al. (2004) and Pool et al. (2010) defined recovery as 'completely recovered' or 'much improved', as reported by the patient. Wirth et al. (2016) defined recovery as "much better" or "better" on their 7-point Likert scale (Wirth et al., 2016). Vos et al. (2008) analyzed only the group that reported 'completely recovered' in their univariate regression analysis. Five studies presented univariate- and multivariate analyses. Wirth et al. (2016) only presented the outcomes of the multivariate analyses.

\subsection{Risk of bias within studies}

The two reviewers agreed $100 \%$ on the overall score regarding RoB using the QUIPS tool for all studies. On average there was low RoB in study participation, prognostic factor measurement and outcome measurement. The highest RoB was found in 'study confounding' and 'study attrition' across the six assessed studies. The following Table 4 outlines the results of the RoB assessment.

\subsection{Synthesis of results}

We conducted a qualitative data synthesis for both univariate and multivariate results and for each different follow-up period, taking into account the number of studies and their methodological quality.

The included studies analyzed a total of 47 and 43 variables for the outcome variables 'pain intensity' and 'perceived non-recovery', respectively.

At three months follow-up, 18 prognostic factors were investigated for 'pain' as outcome variable. There were no studies at six months for pain, and 34 prognostic factors were investigated in univariate analyses at 12 months follow-up. Multivariate analyses were found in three studies (Pool et al., 2010; Hoving et al., 2004; Hill et al., 2004) with follow up at three or 12 months.

Two studies (Schellingerhout et al., 2010; Hill et al., 2004) used poor recovery as their main outcome variable and four studies (Pool et al., 2010; Hoving et al., 2004; Wirth et al., 2016; Vos et al., 2008) used good recovery as their main outcome variable. For perceived nonrecovery, 18 prognostic factors were investigated in univariate analyses at three months and six months follow-up, and 23 prognostic factors at 12 months follow-up. Multivariate analyses were reported in five studies (Pool et al., 2010; Hoving et al., 2004; Wirth et al., 2016; Vos et al., 2008; Schellingerhout et al., 2010) with follow up at three, six or 12 months. However, these studies only reported on the significantly associated variables and not on which factors were included in the primary multivariate analysis.

We present the syntheses of the results for the univariate analysis for the outcome variable 'pain' in Table 5 and the outcome variable 'perceived non-recovery' in Table 6 . The description of the multivariate analyses, for both outcome variables, are presented in Table 7. The extensive description and the syntheses of the results can be found in Appendix 3 and 4.

\subsection{Pain intensity}

In total 47 variables were tested for their prognostic significance (Table 5) in three studies; one high RoB study with a follow-up at three months (Pool et al., 2010) and two high RoB studies (Hoving et al., 2004; Hill et al., 2004) with a follow-up of 12 months. Only 16 of these 47 variables had a statistically significant association with higher pain, while two of the 47 variables had a statistically significant association with decreased pain.

Based on the univariate- and multivariate analysis (Pool et al., 2010; Hoving et al., 2004; Wirth et al., 2016; Vos et al., 2008; Schellingerhout et al., 2010; Hill et al., 2004) we found moderate evidence for 'age $>40$ years' and 'concomitant back pain' to be prognostic for 'pain intensity' at 12 months follow-up. Two high RoB studies found these variables to be significant in these analyses.

Based on the univariate analyses we found conflicting evidence for the variables 'female gender' and 'neck injury/traumatic cause' at 12 months follow-up (Hoving et al., 2004; Hill et al., 2004).

As each of in total 16 variables was only measured in one study (Pool et al., 2010; Hoving et al., 2004; Hill et al., 2004), we considered these variables as having limited evidence for an association with higher pain. Five of these 18 variables were measured at three months, and 11 variables at 12 months.

In multivariate analyses (Table 7) only older age and concomitant LBP were retained in the model in more than one study, confirming moderate evidence for these variables. Distress was retained as a significant prognostic variable in the multivariate analyses at 12 months in one study with high RoB, which was considered as limited evidence (Pool et al., 2010).

\subsection{Perceived non-recovery}

Perceived non-recovery was measured in five studies at three (Pool et al., 2010; Wirth et al., 2016), six (Schellingerhout et al., 2010), and twelve (Hoving et al., 2004; Vos et al., 2008; Hill et al., 2004) months follow-up. In total, 43 variables were tested on their prognostic value (Table 6).

We found moderate evidence for a 'previous period of neck pain' and 'accompanying headache' at 12 months. The results of Vos et al. (2008) showed a significant association with non-recovery, Hoving et al. (2004) showed the similar results, however the association was nonsignificant. We therefore considered this as moderate evidence.

We found limited evidence for 'accompanying headache' and an 'increased fear of movement (TSK)' for perceived non-recovery and 'female gender' for perceived non-recovery at three months. At six months

Table 4

Risk of bias QUIPS-tool.

\begin{tabular}{|c|c|c|c|c|c|c|c|}
\hline Studies & $\begin{array}{l}\text { Study } \\
\text { Participation }\end{array}$ & $\begin{array}{l}\text { Study } \\
\text { Attrition }\end{array}$ & $\begin{array}{l}\text { Prognostic Factor } \\
\text { Measurement }\end{array}$ & $\begin{array}{l}\text { Outcome } \\
\text { measurement }\end{array}$ & $\begin{array}{l}\text { Study } \\
\text { Confounding }\end{array}$ & $\begin{array}{l}\text { Statistical Analysis } \\
\text { and reporting }\end{array}$ & $\begin{array}{l}\text { Overall } \\
\text { score }\end{array}$ \\
\hline Hoving et al. (Hoving et al., 2004) & Low & Low & Low & Low & High & Low & High \\
\hline Hill et al. (Hill et al., 2004) & Low & Moderate & Low & Low & Low & Low & High \\
\hline Vos et al. (Vos et al., 2008) & Low & Moderate & Low & Low & Moderate & Moderate & High \\
\hline Pool et al. (Pool et al., 2010) & Moderate & Moderate & Low & Low & High & Moderate & High \\
\hline $\begin{array}{l}\text { Schellingerhout et al. } \\
\quad \text { (Schellingerhout et al., 2010) }\end{array}$ & Moderate & Low & Low & Low & Moderate & High & High \\
\hline Wirth et al. (Wirth et al., 2016) & Low & High & High & Low & High & Low & High \\
\hline
\end{tabular}


Table 5

Univariate level of evidence of positive association with a higher pain intensity.

\begin{tabular}{|c|c|c|}
\hline Prognostic factors & 3 months & 12 months \\
\hline \multicolumn{3}{|l|}{ Social demographic } \\
\hline Age $\geq 40$ years & & + \\
\hline \multicolumn{3}{|l|}{ Age $18-29$ years (ref) } \\
\hline $30-44$ years & & + \\
\hline $45-59$ years & & $+^{*}$ \\
\hline $60-75$ years & & $+^{*}$ \\
\hline Age (in years) & + & \\
\hline Gender (female) & $+^{*}$ & $+/-$ \\
\hline \multicolumn{3}{|l|}{ Social class } \\
\hline \multicolumn{3}{|l|}{ - $\quad$ Nonmanual (ref) } \\
\hline - Manual & & + \\
\hline \multicolumn{3}{|l|}{ Marital status } \\
\hline \multicolumn{3}{|l|}{ - $\quad$ Married/partner } \\
\hline - Other & & + \\
\hline \multicolumn{3}{|l|}{ Children } \\
\hline \multicolumn{3}{|l|}{ - $\quad$ None (ref) } \\
\hline-1 & & - \\
\hline$-\quad 2$ & & + \\
\hline$-\quad \geq 3$ & & + \\
\hline Nonworking & & $+^{*}$ \\
\hline \multicolumn{3}{|l|}{ Symptoms } \\
\hline Low Back Pain & & $+^{*}$ \\
\hline Pain intensity at baseline & + & $+*$ \\
\hline Severity of complaints & $+^{*}$ & \\
\hline \multicolumn{3}{|l|}{ Duration of the neck pain } \\
\hline \multicolumn{3}{|l|}{ - $\quad$ 2-6 weeks (ref) } \\
\hline - $\quad 7-12$ weeks & & + \\
\hline$-\quad \geq 13$ weeks & & $+^{*}$ \\
\hline Radiating pain below elbow & & + \\
\hline Headache (of cervical origin) & & + \\
\hline No change in neck pain previous 2 weeks & & + \\
\hline Disturbed sleep due to neck pain & & + \\
\hline High severity of physical dysfunctioning & & + \\
\hline \multicolumn{3}{|l|}{ GCPS (grade) } \\
\hline$-\quad 1=$ low intensity (ref) & & \\
\hline
\end{tabular}




\begin{tabular}{|c|c|c|}
\hline & & \\
\hline - $\quad 2$ = high intensity & - & \\
\hline - $\quad 3=$ moderately limiting & + & \\
\hline$-\quad 4=$ severely limiting & + & \\
\hline Prior conditions/ cause problen & & \\
\hline Previous episodes of neck pain & + & $+^{*}$ \\
\hline Neck injury/ Traumatic cause & & $+/-$ \\
\hline Physical activities & & \\
\hline Standing/walking in last job $\geq 2$ hours & & + \\
\hline Driving in last job $\geq 4$ hours & & - \\
\hline Digging/shoveling in last job & & - \\
\hline Sitting in last job $\geq 2$ hours & & - \\
\hline Lifting in last job $\geq 25 \mathrm{lb}$ weights & & $+*$ \\
\hline Gardening at last once or twice a week & & $+*$ \\
\hline Do-it-yourself work often & & + \\
\hline Walking each day > $30 \mathrm{~min}$ & & + \\
\hline Cycling each day & & $+*$ \\
\hline TV hours $>3$ hours per day & & - \\
\hline Physical activity last than average & & $+*$ \\
\hline Psychological factors & & \\
\hline Catastrophizing (PCCL) & + & \\
\hline Coping (PCCL) & + & \\
\hline Internal pain control (PCCL) & - & \\
\hline External pain control (PCCL) & + & \\
\hline TSK (higher score) & $+*$ & \\
\hline Somatization (4DSQ) & $+*$ & \\
\hline Fear (4DSQ) & $+*$ & \\
\hline
\end{tabular}




$$
\begin{aligned}
& \text { Distress (4DSQ) } \\
& \text { Depression (4DSQ) } \\
& \text { Job satisfaction } \\
& \text { Satisfaction at not w } \\
& \text { General health } \\
& \text { BMI } \\
& -\quad<22.5 \text { (ref) } \\
& -\quad 22.5-25.0 \\
& -\quad 25.1-27.4 \\
& -\quad \geq 27.5
\end{aligned}
$$

\section{General health}

Satisfaction at not working

Smoking status

$$
\begin{array}{ll}
\text { - } & \text { Never (ref) } \\
\text { - } & \text { Past } \\
\text { - } & \text { Current }
\end{array}
$$

Alcohol intake $<3$ days per week (ref) $>3$ days per week

Perceived General Health

$$
\text { - Excellent (ref) }
$$

- Good

- Fair

- Poor

GHQ

$-<8$ (ref)

- 8-11

- $12-17$

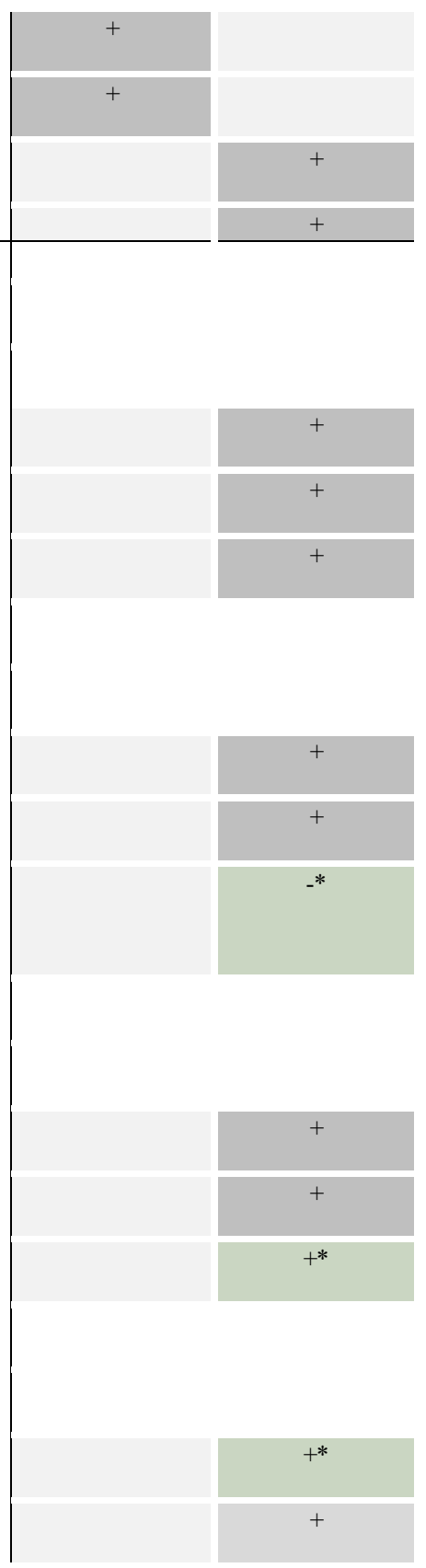

(continued on next page) 


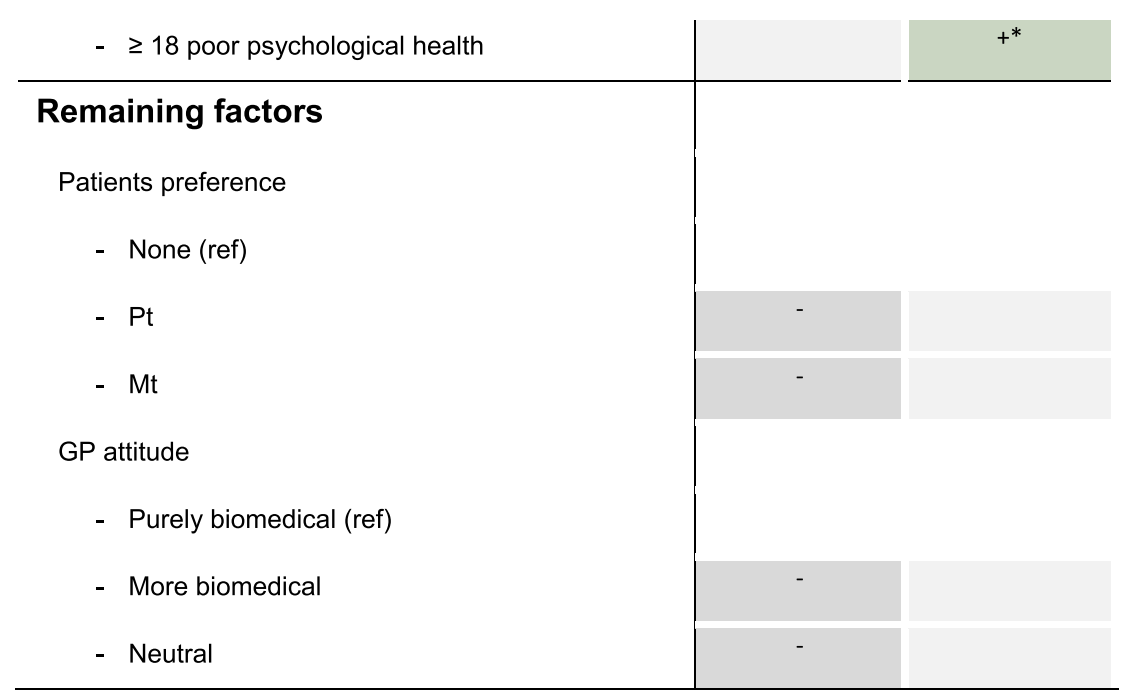

\footnotetext{
$+=$ positive association of prognostic factor with a higher pain intensity

- = negative association of prognostic factor with a higher pain intensity

* = Significant prognostic value
}

\author{
GCPS = Graded Chronic Pain Scale. GHQ = general health questionnaire. GP = General Practioner . \\ $P C C L=$ Pain Coping and Cognition list. $T S K=$ Tampa Scale of Kinesiophobia. \\ $4 D S Q=F o u r$ Dimension Psychological Symptomatology Questionnaire.
}

\title{
$\begin{array}{llll}\text { Strong } & \text { Moderate Limited } & \text { Conflicting }\end{array}$
}

follow-up limited evidence was found for 10 variables (Schellingerhout et al., 2010). With regard to one-year follow-up, nine variables in one study had a statistically significant association with perceived non-recovery and were considered as limited evidence (Hoving et al., 2004; Vos et al., 2008; Hill et al., 2004). One factor (GP advice to wait and see) had a positive impact on recovery (Vos et al., 2008).

In one multivariate analysis, depression was not retained as a significant prognostic factor at three months (Pool et al., 2010), but was retained in another study (Table 7). (Wirth et al., 2016) At six months seven variables were found to be significantly associated with non-recovery (Schellingerhout et al., 2010). Three studies tested prognostic factors at 12 months in a multivariate analysis (Pool et al., 2010; Hoving et al., 2004; Vos et al., 2008). No common factor across the three studies was identified that was significantly associated with persistent complaints defined as non-recovery.

Based on the analysis of the multivariable models we found no prognostic factor that was retained as significant in more than one model (Table 7). This does not lend support for the evidence of some prognostic factors found in the univariate analyses.

\subsection{Quality of evidence}

We present the assessment of the modified GRADE in Appendix 5 and 6 . We included 5 primary studies (phase 1 ) and one phase 3 study. The quality of evidence was downgraded for all prognostic factors researched in the primary studies. We also downgraded all prognostic factors on 'study limitation' due to the high risk of bias assessed with the QUIPS tool (Table 4). 'Publication bias', 'imprecision' and 'inconsistency' were for most of the prognostic factors not applicable due to the limited number of included studies, resulting in a limitation (down) grading. When a prognostic factor showed consistent evidence over different follow-up periods, 'inconsistency' was graded as no serious limitation. No serious limitations for 'imprecision' were graded when there were 2 included studies on one prognostic factor, large enough sample sizes and no intervals reported in both no effect and appreciable risk and protective values. There were no serious limitations on 'indirectness'. We could only increase the quality of evidence for moderate effect size for a few prognostic factors with an OR of $>2.5$. For the outcome variable pain intensity we found only low quality evidence for the prognostic factor 'older age'. For the outcome variable perceivedrecovery we found only low quality evidence for 'older age' and 'accompanying headache', and low back pain, a previous episode of neck pain and a higher score on the TSK at 6 months. For the other prognostic factors we had to downgrade the quality of evidence to very low.

\section{Discussion}

We systematically synthesized the evidence of prognostic factors for the development of chronic musculoskeletal neck pain or perceived non-recovery after a first episode of idiopathic, non-traumatic neck pain. We found moderate evidence for 'age $>40$ years' and 'concomitant back pain' to be prognostic for 'pain intensity'. For the outcome 'perceived non-recovery', we found moderate evidence for both 'a previous period of neck pain' and 'accompanying headache'. However, we found only low or very low quality evidence for these prognostic factors.

Other studies found similar prognostic factors in musculoskeletal problems (Artus et al., 2017; Bier et al., 2017; Mallen et al., 2007; 
Table 6

Univariate level of evidence of positive association with perceived non-recovery.

\begin{tabular}{|c|c|c|c|}
\hline Prognostic factors & 3 months & 6 months & 12 months \\
\hline \multicolumn{4}{|l|}{ Social demographic } \\
\hline Age $\geq 40$ years & + & & $+*$ \\
\hline Age (in years) & + & $-*$ & \\
\hline Age-square & & $+*$ & \\
\hline Gender (female) & + & - & $+* /-$ \\
\hline \multicolumn{4}{|l|}{ Level of education } \\
\hline - $\quad$ High (ref) & & & \\
\hline - $\quad$ Middle & & + & \\
\hline - Low & & + & \\
\hline Employment status (yes $=1$ ) & & - & \\
\hline \multicolumn{4}{|l|}{ Symptoms } \\
\hline Low Back Pain & & $+^{*}$ & $+^{*}$ \\
\hline Severe initial pain & + & - & + \\
\hline Severe initial pain square & & $+*$ & \\
\hline Severity of complaints & - & & \\
\hline Duration of complaints $>2$ weeks & & & $+^{*}$ \\
\hline \multicolumn{4}{|l|}{$>$ Duration current episode } \\
\hline - $\quad 1-3$ months & & - & + \\
\hline - $\quad>3$ months & & + & + \\
\hline Pain in the upper part of the neck & & & $+^{*}$ \\
\hline Accompanying headache & $+^{*}$ & $+^{*}$ & $+^{*}$ \\
\hline Radiating pain below elbow & & & + \\
\hline
\end{tabular}


Table 6 (continued)

Radiating to the back

Radiating pain ( yes $=1$ )

No change in neck pain previous 2 weeks

Disturbed sleep due to neck pain

Accompanying dizziness $($ yes $=1$ )

High severity of physical dysfunction

GCPS (grade)

- $1=$ low intensity (ref)

- $\quad 2$ = high intensity

- $\quad 3=$ moderately limiting

- $\quad 4=$ severely limiting

Total score on the NDI (higher score)

Total score on the ALBPSQ

Prior conditions/ cause problem

Previous episodes of neck pain

Traumatic cause

Psychological factors

Catastrophizing (PCCL)

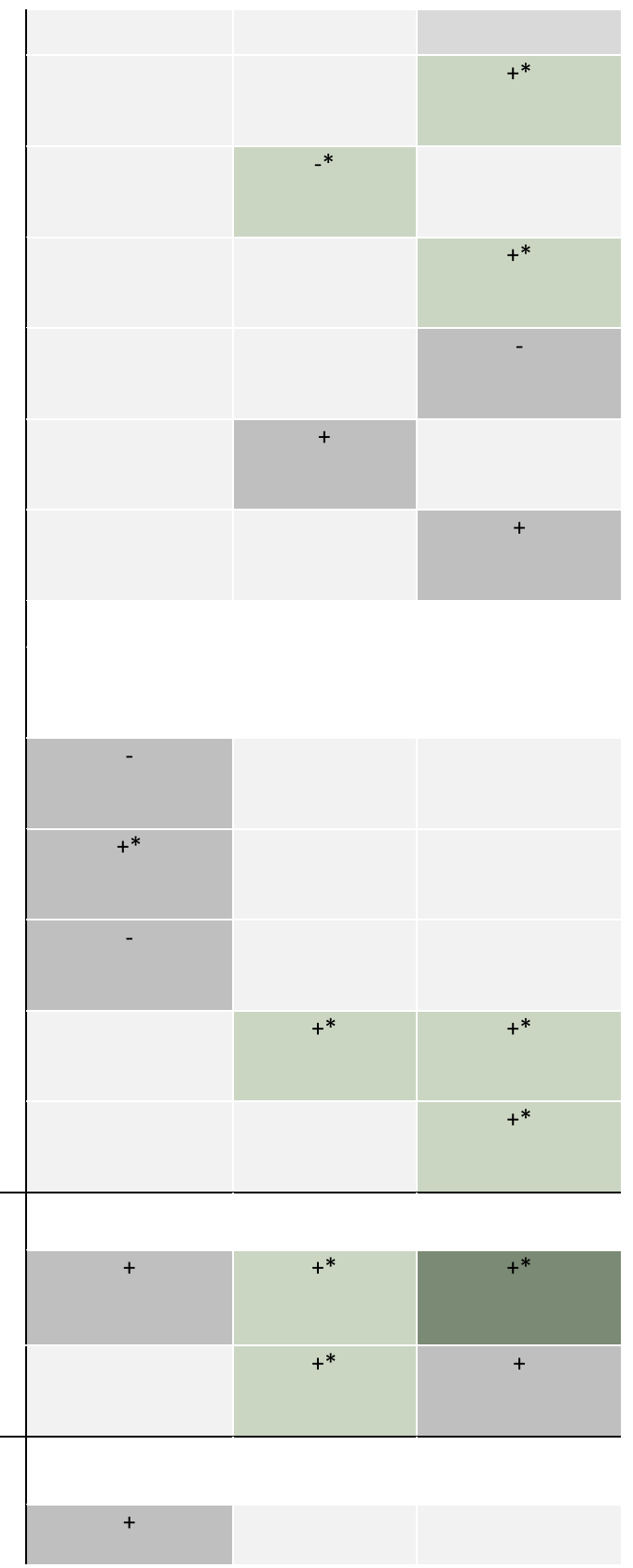

(continued on next page) 
Table 6 (continued)

Coping (PCCL)

Internal pain control (PCCL)

External pain control (PCCL)

TSK (higher score)

Somatization

Fear (4DSQ)

Distress (4DSQ)

Depression (4DSQ)

\section{General health}

EuroQOL VAS
Remaining factors
Patients preference
- None (ref)
- Pt
- Mt
GP attitude
- Purely biomedical (ref)
- More biomedical
- Neutral

Treated for neck pain in the past (yes=1)

Treated by physiotherapist before

Treated by manual therapist before

GP advised to wait and see

GP advised to improve posture

GP prescribed medication

GP instructed in physical exercises

$+\quad=$ positive association of prognostic factor with perceived non-recovery

- $\quad$ = negative association of prognostic factor with perceived non-recovery

* $\quad$ Significant prognostic value

$A L B P S Q=$ Acute Low Back Pain Screening Questionnaire EuroQOL $=$ Quality of Life Scale. GCPS = Graded Chronic Pain Scale. GP = General Practioner. NDI = Neck Disability Index. $P C C L=$ Pain Coping and Cognition list. $T S K=$ Tampa Scale of Kinesiophobia. $4 D S Q=$ Four Dimension Psychological Symptomatology Questionnaire 


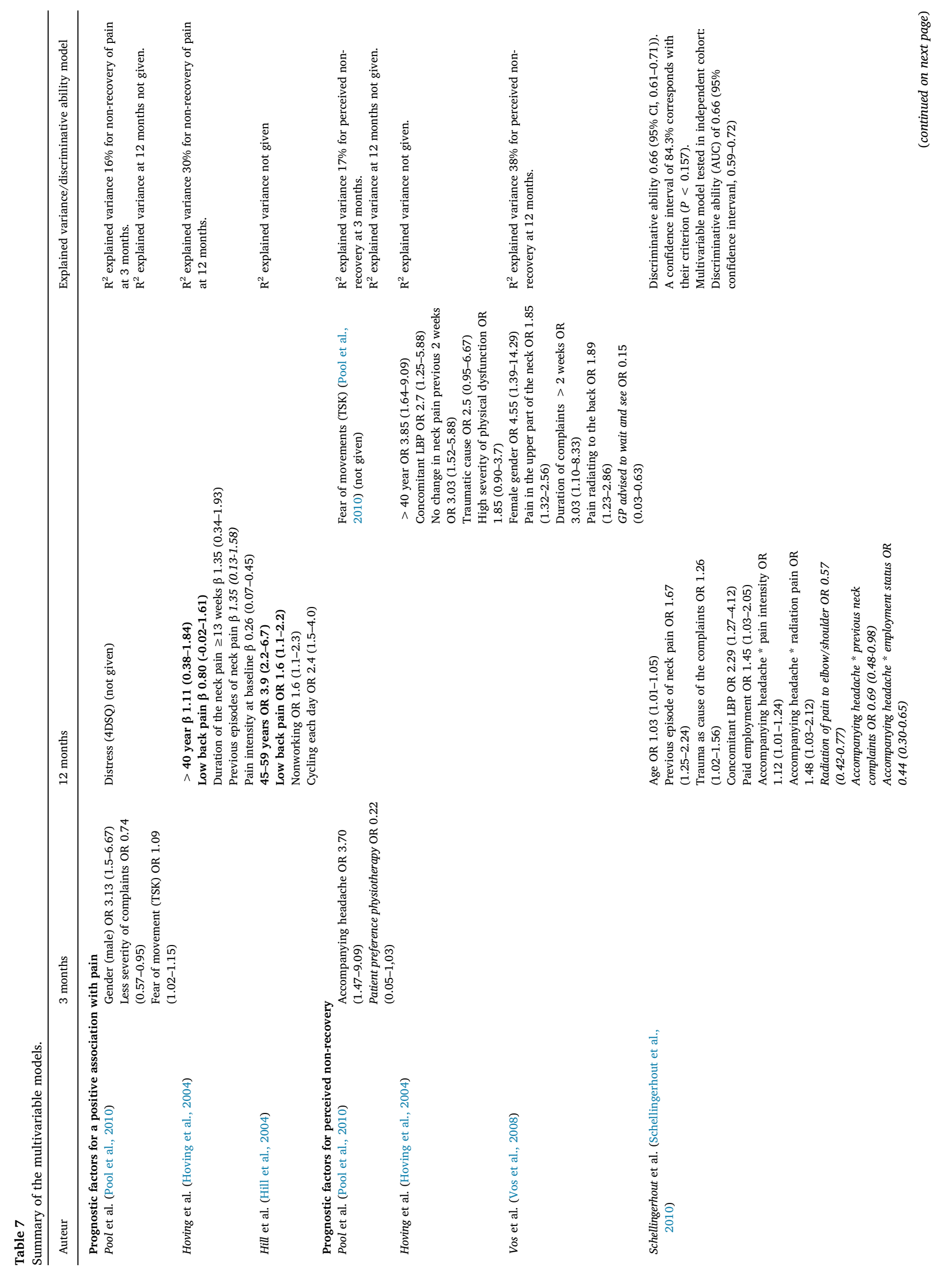


Walton et al., 2013). Concomitant headache and low back pain (LBP) were found to be prognostic for 'chronicity' after an acute whiplash injury (Walton et al., 2013) and for 'time to recover' from a new episode of idiopathic neck pain (Leaver et al., 2013). A previous episode of pain has been reported as a generic prognostic factor for musculoskeletal pain (Artus et al., 2017; Mallen et al., 2007) and chronic WAD (Walton et al., 2013). Were Mallen et al. (2007) and Leaver et al. (2013) found 'older age' of prognostic value.

Posttraumatic stress symptoms, passive coping and high catastrophizing are prognostic factors for chronification of WAD (Walton et al., 2013; Campbell et al., 2018). Avoidance beliefs, catastrophizing, depressive symptoms and distress were found to be prognostic factors for chronification of LBP (Wertli et al., 2014a, 2014b; George and Beneciuk, 2015; Nicholas et al., 2011). The literature found similar psychological problems (e.g. psychological stress, anxiety, fear-avoidance beliefs and catastrophizing) associated with chronic idiopathic, non-traumatic neck pain (Ortego et al., 2016; Thompson et al., 2010; Landers et al., 2008). It is therefore surprising that in prognostic studies on the persistence of acute idiopathic neck pain so very few of these modifiable psychological variables were researched. Only one study (Pool et al., 2010) included a number of relevant psychological variables on both outcome variables at 3 months. Hill et al. (2004) measured two psychological variables for the outcome variable pain at 12 months, whereas Schellingerhout et al. (2010) and Wirth et al. (2016) measured 'kinesiophobia' and 'depression', respectively, as a modifiable variable at 6 and 3 months, respectively, on perceived non-recovery.

We assessed study quality with the QUIPS-tool. The QUIPS-tool considers an overall high RoB when only one of the six-domains is of moderate or high RoB. We are well aware that the QUIPS-tool does not make any difference in degree of bias and is thereby strict in its conclusions. However, the overall high RoB is comparable with other systematic reviews that have included the same studies (Wingbermühle et al., 2018; Kelly et al., 2017).

\subsection{Strengths and limitations}

Our study contributes to the literature by identifying prognostic factors for chronicity in patients with idiopathic, non-traumatic acuteand/or sub-acute neck pain. We do so by only reviewing studies of which at least $60 \%$ of the population consisted of these patients. Ideally, all studies that included patients with chronic neck pain and/or with a traumatic cause would be excluded from the review. However, this would have resulted in an even much lower number of studies making it impossible to synthesize any evidence. We only found six studies, five of which were phase 1 explanatory studies. For example, the study of Schellingerhout et al. (2010) included data from one RCT on chronic neck pain (34\% of subjects), which explains why variables such as 'duration of complaints $\geq 13$ weeks' and 'traumatic cause' were included in this review. Consequently, one cannot consider these variables as prognostic factors for the group of patients with idiopathic, acute- and sub-acute neck pain although they could have influenced the outcomes of these specific studies (Hoving et al., 2004; Schellingerhout et al., 2010; Hill et al., 2004).

A strength of our study is that we did not only judge the level of evidence, but that we also critically assessed the quality of our findings. This allowed to distinguish between level and quality of evidence, and hence, for a more reliable assessment of the results of existing studies.

The results found in our systematic review have to be interpreted with caution. A first point of attention is that Vos et al. (2008) used a CI of $90 \%$ in their univariate analysis whereas the other five studies (Pool et al., 2010; Hoving et al., 2004; Wirth et al., 2016; Schellingerhout et al., 2010; Hill et al., 2004) used a CI of 95\%. In the multivariate analysis five studies (Pool et al., 2010; Hoving et al., 2004; Wirth et al., 2016; Vos et al., 2008; Hill et al., 2004) used a 95\% CI; Schellingerhout et al. (2010), however, used a CI of $84.3 \%$. By using a smaller confidence interval the chance that type 1 errors occurs increases 
(Akobeng, 2016).

Second, we included studies that used data from randomized clinical trials (Pool et al., 2010; Hoving et al., 2004; Schellingerhout et al., 2010). It is questionable whether data from randomized clinical trials are appropriate to identify modifiable variables for persistent pain or non-recovery. The applied therapy could have affected the found associations: if the therapy is effective, these patients will experience less or no pain, and the effect of the prognostic factors is mitigated. The effect of treatment can be seen as an effect modifier (Hancock et al., 2009). Prognostic factors could be at best researched in the non-treatment or placebo arm of RCT's (Adolfsson and Steineck, 2000), instead of adjusting for intervention in regression analysis.

Third, there is still some uncertainty about the exact sample composition and the analyzed factors in the study from Schellingerhout et al. (2010) as this study pooled data from three other studies (Pool et al., 2010; Hoving et al., 2004; Vonk et al., 2009). These three studies, however, analyzed different factors and also used different selection criteria for their cohorts. Combining these studies therefore resulted in large amounts of missing data for some of the variables. It is not clear how the authors dealt with missing data. We therefore have to interpret these findings with caution.

Fourth, despite the fact that the included studies used a similar tool for measuring perceived recovery, they interpreted it differently in their data analyses. While Vos et al. (2008) analyzed only the group who was 'completely recovered' as recovered, Hoving et al. (2004) and Pool et al. (2010) also included the group who were 'much improved'. Wirth et al. (2016) considered 'much better' and 'better' as recovered. Based on these different interpretations, it can be questioned whether the results for this outcome variable can be compared. In addition, the prognostic variables have to be well described and measured with valid tools. The included studies used different tools for measuring the same construct, for instance depression (Pool et al., 2010; Wirth et al., 2016). Additionally, the interpretation of some variables is unclear. Pool et al. (2010) measured 'pain at inception' and 'severity of complaints' at baseline. It is unclear whether practitioners and patients can differentiate between the two. We therefore recommend to develop a Core Outcome Set for neck pain and the use of consistent measurements and definitions for the dependent and independent variables in further research. Only then is it possible to obtain valuable evidence and useful data for practice.

Another limitation of our study could be that we did not include secondary measures, such as pain related disability. However, it is known that pain and disability are distinct constructs as not every person with persistent pain also experiences disability (Lee et al., 2015). Nevertheless from a clinical and health perspective neck-related disability and work status are important outcomes, and further research should measure pain intensity, disability and work status as distinct dimensions of persistent pain. However, identifying prognostic factors for disability and work status was beyond the scope of this review.

\subsection{Further research}

The focus in health care must be on the prevention of chronic pain. As mentioned above, chronic neck pain influences not only quality of life, but also impacts health care costs worldwide. Prevention is therefore key in combatting this, and opportunities for the prevention of chronicity only exist in acute- and subacute patients.

Given that we found no low RoB study, and because of the specific limitations as outlined above, there is much need for a conclusive and comprehensive cohort study on prognostic factors for chronification of acute- or subacute idiopathic, non-traumatic, neck pain. Special attention must be given to modifiable prognostic factors.

\section{Conclusion}

We have identified moderate and limited evidence to support the presence of a number of prognostic factors in patients with acute or subacute musculoskeletal, non-traumatic neck pain that are associated with pain or perceived non-recovery up until one year after onset of pain. Such factors include higher age ( $>40$ years), concomitant LBP or headache and a previous period of neck pain. Nevertheless, the quality of this evidence is graded as low to very low. Further research is needed before drawing definite conclusions about the prognostic value of these factors.

\section{Acknowledgements}

The authors thank Jurgen Mollema, Utrecht University of Applied Sciences, for the assistance with the search strategy, and Cas Kruitwagen, Utrecht University, for the helpful comments on the statistical analysis.

\section{Appendix 1. Search strategy}

Review question

Which factors predict the development of chronic musculoskeletal neck pain after a first episode of idiopathic, non-traumatic neck pain?

\section{MEDLINE (PubMed)}

(chronic OR "non specific" OR nonspecific OR "long standing" OR longstanding OR persistent) AND ("Neck Pain” [Mesh] OR neck pain [tiab] OR neckache* [tiab] OR neck ache*[tiab] OR cervicodynia*[tiab] OR cervicalgia*[tiab] OR cervical pain [tiab] OR cervical ache [tiab] OR cervical aches [tiab]) AND (factor*[tiab] OR affordance*[tiab] OR constraint*[tiab] OR obstacle*[tiab] OR impediment*[tiab] OR enabler*[tiab] OR motivat*[tiab] OR inhibit*[tiab] OR stimulat*[tiab] OR correlat*[tiab] OR determin*[tiab] OR facilitat*[tiab] OR barrie*[tiab])

\section{PsycINFO(OVID)}

((chronic OR non specific OR nonspecific OR long standing OR longstanding OR persistent) AND (neck pain OR neckache* OR neck ache* OR cervicodynia* OR cervicalgia* OR cervical pain OR cervical ache*) AND (factor* OR affordance* OR constraint* OR obstacle* OR impediment* OR enabler* OR motivat* OR inhibit* OR stimulat* OR correlat* OR determin* OR facilitat* OR barrie*)). mp.

\section{Embase(Elsevier)}

chronic OR 'non specific' OR nonspecific OR 'long standing' OR longstanding OR persistent AND ('neck pain'/exp OR neckache* OR 'neck ache*' OR cervicodynia* OR cervicalgia* OR 'cervical pain' OR 'cervical ache*') AND (factor* OR affordance* OR constraint* OR obstacle* OR impediment* OR enabler* OR motivat* OR inhibit* OR stimulat* OR correlat* OR determin* OR facilitat* OR barrie*) AND [embase]/lim. 


\section{SPORTDiscus(EBSCO)}

(chronic OR "non specific" OR nonspecific OR "long standing" OR longstanding OR persistent) AND (DE "NECK pain" OR "neck pain" OR neckache* OR "neck ache*" OR cervicodynia* OR cervicalgia* OR "cervical pain" OR "cervical ache*") AND (factor* OR affordance* OR constraint" OR obstacle* OR impediment* OR enabler* OR motivat* OR inhibit* OR stimulat* OR correlat* OR determin* OR facilitat* OR barrie*)

\section{CINAHL(EBSCO)}

(chronic OR "non specific" OR nonspecific OR "long standing" OR longstanding OR persistent) AND (MH "Neck Pain" OR "neck pain" OR neckache* OR "neck ache*" OR cervicodynia* OR cervicalgia* OR "cervical pain" OR "cervical ache*") AND (factor* OR affordance* OR constraint* OR obstacle* OR impediment* OR enabler* OR motivat* OR inhibit* OR stimulat* OR correlat* OR determin* OR facilitat* OR barrie*)

Grey literature databases

Dart Europe: "neck pain" AND factor*

Open access Theses and Dissertations: "neck pain" AND factor*

NDLTD: "neck pain" AND factor"

Clinical trials. gov: "neck pain" AND factor"

WHO ICTRP: "neck pain" AND factor"

\section{Appendix 2. Data extraction table}

\begin{tabular}{|c|c|c|c|c|c|c|c|c|c|c|}
\hline Authors & Population & $\begin{array}{l}\mathrm{N} \text { (at base- } \\
\text { line) }\end{array}$ & Patients characteristics & $\begin{array}{l}\text { Mean age } \\
\text { (SD) }\end{array}$ & $\begin{array}{l}\text { Outcome } \\
\text { variables }\end{array}$ & $\begin{array}{l}\text { Follow- } \\
\text { up } \\
\text { period }\end{array}$ & $\begin{array}{l}\text { N (at follow- } \\
\text { up) }\end{array}$ & $\begin{array}{l}\text { Statistical } \\
\text { analyses }\end{array}$ & Recovery & $\begin{array}{l}\text { Quality } \\
\text { of the } \\
\text { study } \\
\text { (QUIPS) }\end{array}$ \\
\hline $\begin{array}{l}\text { Hoving et al. (Hoving } \\
\text { et al., 2004) }\end{array}$ & GP NL & $\begin{array}{l}183 \\
60.7 \% \mathrm{~F}\end{array}$ & $\begin{array}{l}\text { Pain and/or stiffness of the } \\
\text { neck for at least two weeks } \\
\text { Previous } 6 \text { months no pain }\end{array}$ & $\begin{array}{l}66.7 \% \\
>-40 \mathrm{yrs}\end{array}$ & $\begin{array}{l}\text { Pain inten- } \\
\text { sity NRS } \\
\text { PGIC }\end{array}$ & $\begin{array}{l}7 \text { and } 52 \\
\text { weeks }\end{array}$ & $\begin{array}{l}7 \text { weeks } \\
183(100 \%) \\
52 \text { weeks } \\
178(97 \%)\end{array}$ & $\begin{array}{l}\text { Logistic re- } \\
\text { gression } \\
\text { analysis } \\
\text { Multiple re- } \\
\text { gression }\end{array}$ & $\begin{array}{l}7 \text { weeks } \\
51.4 \% \\
52 \text { weeks } \\
63.4 \% \text { re- } \\
\text { covered }\end{array}$ & $\begin{array}{l}\text { High } \\
\text { Risk of } \\
\text { bias }\end{array}$ \\
\hline $\begin{array}{l}\text { Hill et al. (Hill et al., } \\
\text { 2004) }\end{array}$ & $\begin{array}{l}\text { Adults gen- } \\
\text { eral popula- } \\
\text { tion UK }\end{array}$ & $\begin{array}{l}1359 \\
61 \% \mathrm{~F} \\
\text { (follow-up } \\
\text { responders) }\end{array}$ & $\begin{array}{l}1 \text { month period prevalent } \\
\text { neck pain }\end{array}$ & $\begin{array}{l}51 \text { yrs } \\
\text { (follow-up } \\
\text { responders) }\end{array}$ & $\begin{array}{l}\text { Persistent } \\
\text { neck pain }\end{array}$ & $\begin{array}{l}12 \\
\text { months }\end{array}$ & $786(58 \%)$ & $\begin{array}{l}\text { Logistic re- } \\
\text { gression } \\
\text { analysis } \\
\text { Multiple re- } \\
\text { gression }\end{array}$ & $\begin{array}{l}381(48 \%) \\
\text { neck pain } \\
\text { after } 1 \text { year }\end{array}$ & $\begin{array}{l}\text { High } \\
\text { Risk of } \\
\text { bias }\end{array}$ \\
\hline $\begin{array}{l}\text { Vos et al. (Vos et al., } \\
\text { 2008) }\end{array}$ & GP NL & $\begin{array}{l}187 \\
64 \% \mathrm{~F}\end{array}$ & $\begin{array}{l}\text { Non-specific neck pain }<6 \\
\text { weeks first episode or after a } \\
\text { pain free period }>3 \text { months }\end{array}$ & $\begin{array}{l}\text { Females } \\
38.2, \mathrm{SD} \\
13.3 \mathrm{yr} \\
\text { Males } 43.2 \text {, } \\
\text { SD } 14.9 \mathrm{yr}\end{array}$ & PGIC & $\begin{array}{l}6,12,26, \\
\text { and } 52 \\
\text { weeks }\end{array}$ & $138(74 \%)$ & $\begin{array}{l}\text { Logistic re- } \\
\text { gression } \\
\text { analysis } \\
\text { Multiple re- } \\
\text { gression }\end{array}$ & $\begin{array}{l}76 \% \text { recov- } \\
\text { ered or } \\
\text { much im- } \\
\text { proved, } \\
47 \% \text { on- } \\
\text { going pain }\end{array}$ & $\begin{array}{l}\text { High } \\
\text { Risk of } \\
\text { bias }\end{array}$ \\
\hline $\begin{array}{l}\text { Wirth et al. (Wirth et- } \\
\text { al., 2016) }\end{array}$ & $\begin{array}{l}\text { Chiropractic } \\
\text { practices } \mathrm{CH}\end{array}$ & $\begin{array}{l}103 \\
60.7 \% \mathrm{~F}\end{array}$ & $\begin{array}{l}\text { First episode acute non-spe- } \\
\text { cific neck pain }<4 \text { weeks }\end{array}$ & $\begin{array}{l}38.3 \mathrm{SD} \\
13.8 \mathrm{yrs}\end{array}$ & PGIC & $\begin{array}{l}\text { One } \\
\text { week, } 1 \\
\text { and } 3 \\
\text { months }\end{array}$ & $82(80 \%)$ & $\begin{array}{l}\text { Logistic re- } \\
\text { gression } \\
\text { analysis } \\
\text { Multiple re- } \\
\text { gression }\end{array}$ & $\begin{array}{l}86.6 \% \mathrm{im}- \\
\text { proved after } \\
3 \text { months }\end{array}$ & $\begin{array}{l}\text { High } \\
\text { Risk of } \\
\text { bias }\end{array}$ \\
\hline $\begin{array}{l}\text { Schellingerhout et al. } \\
\text { (Schellingerhout } \\
\text { et al., 2010) }\end{array}$ & GP NL & $\begin{array}{l}468 \\
61 \% \mathrm{~F}\end{array}$ & $\begin{array}{l}\text { Non-specific neck pain. } \\
\text { Acute - and sub-acute (61\%) }\end{array}$ & $\begin{array}{l}45.4 \mathrm{SD} \\
11.8 \mathrm{yrs}\end{array}$ & PGIC & 6 months & $\begin{array}{l}\text { Missing value } \\
\text { differ per } \\
\text { variable } \\
(1-43 \%)\end{array}$ & $\begin{array}{l}\text { Logistic re- } \\
\text { gression } \\
\text { analysis } \\
\text { Multiple re- } \\
\text { gression }\end{array}$ & $\begin{array}{l}43 \% \text { persis- } \\
\text { tent com- } \\
\text { plaints }\end{array}$ & $\begin{array}{l}\text { High } \\
\text { Risk of } \\
\text { bias }\end{array}$ \\
\hline $\begin{array}{l}\text { Pool et al. (Pool et al., } \\
\text { 2010) }\end{array}$ & GP NL & 146 & Sub-acute neck pain & $\begin{array}{l}45.1 \mathrm{SD} \\
11.2\end{array}$ & $\begin{array}{l}\text { GPE } \\
\text { NRS pain }\end{array}$ & $\begin{array}{l}12 \text { weeks } \\
52 \text { weeks }\end{array}$ & $\begin{array}{l}12 \text { weeks } 146 \\
(100 \%) \\
52 \text { weeks } \\
128(87.7 \%)\end{array}$ & $\begin{array}{l}\text { Logistic re- } \\
\text { gression } \\
\text { analysis } \\
\text { Multiple re- } \\
\text { gression }\end{array}$ & $\begin{array}{l}\text { GPE } 12 \\
\text { weeks: } \\
70.5 \% \\
52 \text { weeks: } \\
77.2 \% \\
\text { NRS } \\
12 \text { weeks: } \\
48.6 \% \\
52 \text { weeks } \\
68.2 \%\end{array}$ & $\begin{array}{l}\text { High } \\
\text { Risk of } \\
\text { bias }\end{array}$ \\
\hline
\end{tabular}

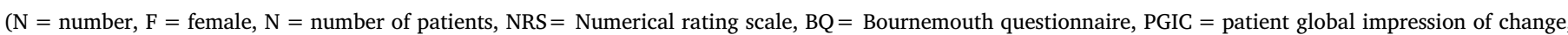
$\mathrm{GPE}=$ Global perceived recovery SD $=$ standard deviation, $\mathrm{GP}=$ general practice, $\mathrm{NL}=$ Netherlands, UK $=$ United Kingdom, $\mathrm{CH}=\mathrm{Switzerland}$ ). 
Appendix 3. Univariate level of evidence of positive association with a higher pain intensity

\begin{tabular}{|c|c|c|c|c|}
\hline Prognostic factors & 3 months & 12 months & Level of Evidence & $\begin{array}{l}\text { Overall Quality of } \\
\text { Evidence }\end{array}$ \\
\hline \multicolumn{5}{|l|}{$\begin{array}{l}\text { Social demographic } \\
\text { characteristics }\end{array}$} \\
\hline $\begin{array}{l}>\text { Age } 40 \\
\text { Hoving et al. } \\
\text { Age } \\
\text { Hill et al. } \\
\text { 18-30 years (ref) } \\
30-44 \text { years } \\
45-59 \text { years } \\
60-75 \text { years }\end{array}$ & & $\begin{array}{l}1.04(0.27-1.80)^{37} \\
1.5(0.9-2.6)^{41} \\
3.4(2.0-5.7)^{\star 41} \\
2.1(1.3-3.4)^{\star 41}\end{array}$ & $\begin{array}{l}\text { Moderate evidence for a positive } \\
\text { association with a higher pain intensity at } 12 \\
\text { months }\end{array}$ & Low \\
\hline $\begin{array}{l}\text { Age (measured in years) } \\
\text { Pool et al. }\end{array}$ & $1.00^{36}$ & & & \\
\hline $\begin{array}{l}\text { Gender (female) } \\
\text { Pool et al. } \\
\text { Hoving et al. } \\
\text { Hill et al. }\end{array}$ & $0.38(0.19-0.76)^{\star 36}$ & $\begin{array}{l}1.0(0.8-1.3)^{41} \\
-0.15(-91-0.60)^{37}\end{array}$ & $\begin{array}{l}\text { Limited evidence for a positive association } \\
\text { with a higher pain intensity at } 3 \text { months }\end{array}$ & Very low \\
\hline $\begin{array}{l}\text { Social class } \\
\quad \text { Hill et al. } \\
\text { Nonmanual (ref) } \\
\text { Manual } \\
\end{array}$ & & $1.1(0.8-1.4)^{41}$ & & \\
\hline $\begin{array}{l}\text { Marital status } \\
\quad \text { Hill et al. } \\
\text { Married/partner (ref) } \\
\text { Other } \\
\end{array}$ & & $1.3(0.9-1.7)^{41}$ & & \\
\hline $\begin{array}{l}\text { Children } \\
\quad \text { Hill et al. } \\
\text { None (ref) } \\
1 \\
2 \\
>-3\end{array}$ & & $\begin{array}{l}0.7(0.4-1.1)^{41} \\
1.2(0.8-1.9)^{41} \\
1.1(0.7-1.6)^{41}\end{array}$ & & \\
\hline $\begin{array}{c}\text { Nonworking } \\
\text { Hill et al. }\end{array}$ & & $1.8(1.3-2.5)^{\star 41}$ & $\begin{array}{l}\text { Limited evidence for a positive association } \\
\text { with a higher pain intensity at } 12 \text { months }\end{array}$ & Very low \\
\hline \multicolumn{5}{|l|}{ Symptoms } \\
\hline $\begin{array}{l}\text { Low Back Pain } \\
\text { Hoving et al. } \\
\text { Hill et al. }\end{array}$ & & $\begin{array}{l}\mathbf{1 . 7}(1.3-2.3)^{\star 41} \\
1.13(0.29-1.97)^{\star 37}\end{array}$ & $\begin{array}{l}\text { Moderate evidence for a positive } \\
\text { association with a higher pain intensity at } 12 \\
\text { months }\end{array}$ & Very low \\
\hline $\begin{array}{l}\text { Pain intensity at baseline } \\
\text { Pool et al. } \\
\text { Hoving et al. }\end{array}$ & $1.10(0.17-1.19)^{36}$ & $0.26(0.07-0.45)^{\star 37}$ & $\begin{array}{l}\text { Limited evidence for a positive association } \\
\text { with a higher pain intensity at } 12 \text { months }\end{array}$ & Very low \\
\hline $\begin{array}{l}\text { Severity of complaints } \\
\text { Pool et al. }\end{array}$ & $0.78(0.61-0.91)^{3.36}$ & & $\begin{array}{l}\text { Limited evidence for a positive association } \\
\text { with a higher pain intensity at } 3 \text { months }\end{array}$ & Very low \\
\hline $\begin{array}{l}\text { Duration of the neck pain } \\
\quad \text { Hoving et al. } \\
2-6 \text { weeks (ref) } \\
7-12 \text { weeks } \\
\text { >-13 weeks }\end{array}$ & & $\begin{array}{l}0.07(-0.76-0.91)^{37} \\
1.03(0.19-1.86)^{\star 37}\end{array}$ & $\begin{array}{l}\text { Limited evidence for a positive association } \\
\text { with a higher pain intensity at } 12 \text { months }\end{array}$ & Very low \\
\hline $\begin{array}{l}\text { Radiating pain below elbow } \\
\text { Hoving et al. }\end{array}$ & & $0.77(-0.23-1.71)^{37}$ & & \\
\hline Headache (of cervical origin) & $1.67(0.81-3.33)^{36}$ & $0.52(-0.29-1.32)^{31}$ & & \\
\hline
\end{tabular}




\begin{tabular}{|c|c|c|c|c|}
\hline $\begin{array}{l}\text { Pool et al. } \\
\text { Hoving et al. }\end{array}$ & & & & \\
\hline $\begin{array}{l}\text { No change in neck pain previous } 2 \\
\text { weeks } \\
\text { Hoving et al. }\end{array}$ & & $0.66(-0.08-1.39)^{37}$ & & \\
\hline $\begin{array}{l}\text { Disturbed sleep due to neck pain } \\
\text { Hoving et al. }\end{array}$ & & $0.33(-0.41-1.06)^{3 T}$ & & \\
\hline $\begin{array}{l}\text { High severity of physical dysfunctioning } \\
\text { Hoving et al. }\end{array}$ & & $0.66(-0,10-1.42)^{37}$ & & \\
\hline $\begin{array}{l}\text { GCPS (grade) } \\
\quad \text { Pool et al. } \\
1=\text { low intensity } \\
2=\text { high intensity } \\
3=\text { Moderately limiting } \\
4=\text { severely limiting }\end{array}$ & $\begin{array}{l}0.75(0.25-2.22)^{36} \\
1.04(0.28-3.85)^{36} \\
1.19(0.33-4.35)^{36}\end{array}$ & & & \\
\hline \multicolumn{5}{|l|}{$\begin{array}{l}\text { Prior conditions/ cause } \\
\text { problem }\end{array}$} \\
\hline $\begin{array}{l}\text { Previous episodes of neck pain } \\
\text { Pool et al. } \\
\text { Hoving et al. }\end{array}$ & $1.03(0.52-2.08)^{36}$ & $0.83(0.06-1.59)^{\star 37}$ & $\begin{array}{l}\text { Limited evidence for a positive association } \\
\text { with a higher pain intensity at } 12 \text { months }\end{array}$ & Very low \\
\hline $\begin{array}{l}\text { Neck injury/ Traumatic cause } \\
\text { Hoving et al. } \\
\text { Hill et al. } \\
\end{array}$ & & $\begin{array}{l}1.5(1.1-2.2)^{\star 41} \\
0.72(-0.71-1.25)^{37}\end{array}$ & $\begin{array}{l}\text { Conflicting evidence for a positive } \\
\text { association with a higher pain intensity at } 12 \\
\text { months }\end{array}$ & Very low \\
\hline \multicolumn{5}{|l|}{ Physical activities } \\
\hline $\begin{array}{l}\text { Standing/walking in last job } \\
\geq 2 \text { hours } \\
\text { Hill et al. }\end{array}$ & & $1.2(0.9-1.7)^{41}$ & & \\
\hline $\begin{array}{l}\text { Driving in last job } \geq 4 \mathrm{hrs} \\
\text { Hill et al. }\end{array}$ & & $0.8(0.5-1.2)^{41}$ & & \\
\hline $\begin{array}{l}\text { Digging/shoveling in last job } \\
\text { Hill et al. }\end{array}$ & & $0.8(0.4-1.7)^{41}$ & & \\
\hline $\begin{array}{l}\text { Sitting in last job } \geq 2 \text { hours } \\
\text { Hill et al. }\end{array}$ & & $0.9(0.6-1.2)^{41}$ & & \\
\hline $\begin{array}{l}\text { Lifting in last job } \geq 25 \mathrm{lb} \text { weights } \\
\text { Hill et al. }\end{array}$ & & $1.3(1.0-1.8)^{\star 41}$ & $\begin{array}{l}\text { Limited evidence for a positive association } \\
\text { with a higher pain intensity at } 12 \text { months }\end{array}$ & Very low \\
\hline $\begin{array}{l}\text { Gardening at last once or twice a week } \\
\text { Hill et al. }\end{array}$ & & $0.8(0.6-1.0)^{\star 41}$ & $\begin{array}{l}\text { Limited evidence for a negative association } \\
\text { with a higher pain intensity at } 12 \text { months }\end{array}$ & Very low \\
\hline $\begin{array}{l}\text { Do-it-yourself work often } \\
\text { Hill et al. }\end{array}$ & & $1.0(0.7-1.4)^{41}$ & & \\
\hline $\begin{array}{l}\text { Walking each day }>30 \mathrm{~min} \\
\text { Hill et al. }\end{array}$ & & $1.1(0.8-1.4)^{41}$ & & \\
\hline $\begin{array}{l}\text { Cycling each day } \\
\text { Hill et al. }\end{array}$ & & $2.0(1.3-3.2)^{* 41}$ & $\begin{array}{l}\text { Limited evidence for a positive association } \\
\text { with a higher pain intensity at } 12 \text { months }\end{array}$ & Very low \\
\hline $\begin{array}{l}\text { TV hours }>3 \text { hrs per day } \\
\text { Hill et al. }\end{array}$ & & $0.9(0.7-1.3)^{41}$ & & \\
\hline $\begin{array}{l}\text { Physical activity } \\
\text { Less than average } \\
\text { Hill et al. }\end{array}$ & & $1.4(1.0-1.9)^{\star 41}$ & $\begin{array}{l}\text { Limited evidence for a positive association } \\
\text { with a higher pain intensity at } 12 \text { months }\end{array}$ & Very low \\
\hline \multicolumn{5}{|l|}{ Psychological factors } \\
\hline $\begin{array}{l}\text { Catastrophizing (PCCL) } \\
\text { Pool et al. }\end{array}$ & $2.38(0.98-5.88)^{36}$ & & & \\
\hline $\begin{array}{l}\text { Coping (PCCL) } \\
\text { Pool et al. }\end{array}$ & $1.12(0.77-1.67)^{36}$ & & & \\
\hline
\end{tabular}




\begin{tabular}{|c|c|c|c|c|}
\hline $\begin{array}{l}\text { Internal pain control (PCCL) } \\
\text { Pool et al. }\end{array}$ & $0.82(0.68-1.41)^{36}$ & & & \\
\hline $\begin{array}{l}\text { External pain control(PCCL) } \\
\text { Pool et al. }\end{array}$ & $1.03(0.72-1.47)^{36}$ & & & \\
\hline $\begin{array}{l}\text { TSK (higher score) } \\
\text { Pool et al. }\end{array}$ & $1.06(1.00-1.12)^{* 36}$ & & $\begin{array}{l}\text { Limited evidence for a positive association } \\
\text { with a higher pain intensity at } 3 \text { months }\end{array}$ & Very low \\
\hline $\begin{array}{l}\text { Somatization (4DSQ) } \\
\text { Pool et al. }\end{array}$ & $1.09(1.01-1.18)^{* 36}$ & & $\begin{array}{l}\text { Limited evidence for a positive association } \\
\text { with a higher pain intensity at } 3 \text { months }\end{array}$ & Very low \\
\hline $\begin{aligned} \text { Fear (4DSQ) } \\
\text { Pool et al. } \\
\end{aligned}$ & $1.75(1.11-2.78)^{* 36}$ & & $\begin{array}{l}\text { Limited evidence for a positive association } \\
\text { with a higher pain intensity at } 3 \text { months }\end{array}$ & Very low \\
\hline $\begin{array}{l}\text { Distress (4DSQ) } \\
\text { Pool et al. } \\
\end{array}$ & $1.39(0.95-2.00)^{36}$ & & & \\
\hline $\begin{array}{l}\text { Depression (4DSQ) } \\
\text { Pool et al. }\end{array}$ & $1.52(0.81-2.86)^{36}$ & & & \\
\hline $\begin{array}{l}\text { Job satisfaction } \\
\text { Hill et al. }\end{array}$ & & $1.1(0.7-1.7)^{41}$ & & \\
\hline $\begin{array}{l}\text { Satisfaction at not working } \\
\text { Hill et al. }\end{array}$ & & $1.4(0.9-2.2)^{41}$ & & \\
\hline \multicolumn{5}{|l|}{ General health } \\
\hline $\begin{array}{l}\text { BMI } \\
\quad \text { Hill et al. } \\
<22.5 \text { (ref) } \\
22.5-25.0 \\
25.1-27.4 \\
>-27.5\end{array}$ & & $\begin{array}{l}1.1(0.8-1.7)^{41} \\
1.0(0.7-1.6)^{41} \\
1.4(0.9-2.1)^{41}\end{array}$ & & \\
\hline $\begin{array}{l}\text { Smoking status } \\
\quad \text { Hill et al. } \\
\text { Never (ref) } \\
\text { Past } \\
\text { Current } \\
\end{array}$ & & $\begin{array}{l}1.1(0.7-1.5)^{41} \\
1.0(0.7-1.6)^{41}\end{array}$ & & \\
\hline $\begin{array}{l}\text { Alcohol intake } \\
\text { Hill et al. } \\
<3 \text { days per week } \\
>3 \text { days per week } \\
\end{array}$ & & $0.7(0.5-0.9)^{\star 41}$ & $\begin{array}{l}\text { Limited evidence for a negative association } \\
\text { with a higher pain intensity at } 12 \text { months }\end{array}$ & Very low \\
\hline $\begin{array}{l}\text { Perceived General health } \\
\quad \text { Hill et al. } \\
\text { Excellent (ref) } \\
\text { Good } \\
\text { Fair } \\
\text { Poor } \\
\end{array}$ & & $\begin{array}{l}1.3(0.8-2.3)^{41} \\
1.5(0.8-2.6)^{41} \\
1.9(1.0-3.7)^{* 41}\end{array}$ & $\begin{array}{l}\text { Limited evidence for a positive association } \\
\text { with a higher pain intensity at } 12 \text { months }\end{array}$ & Very low \\
\hline $\begin{array}{l}\text { GHQ } \\
\quad \text { Hill et al. } \\
<8 \text { (ref) } \\
8-11 \\
12-17 \\
\geq 18 \text { poor psychological health } \\
\end{array}$ & & $\begin{array}{l}1.6(1.0-2.7)^{\star 41} \\
1.5(0.9-2.5)^{41} \\
2.2(1.3-3.6)^{\star 41}\end{array}$ & $\begin{array}{l}\text { Limited evidence for a positive association } \\
\text { with a higher pain intensity at } 12 \text { months }\end{array}$ & Very low \\
\hline \multicolumn{5}{|l|}{ Remaining factors } \\
\hline $\begin{array}{l}\text { Patients preference } \\
\quad \text { Pool et al. } \\
\text { None } \\
\mathrm{Pt} \\
\mathrm{Mt}\end{array}$ & $\begin{array}{l}0.43(0.15-1.23)^{36} \\
0.86(0.39-1.25)^{36}\end{array}$ & & & \\
\hline $\begin{array}{l}\text { GP attitude } \\
\quad \text { Pool et al. } \\
\text { Purely biomedical (ref) } \\
\text { More biomedical }\end{array}$ & $\begin{array}{l}0.67(0.24-1.85)^{36} \\
0.46(0.17-1.12)^{36}\end{array}$ & & & \\
\hline Neutral & & & & \\
\hline
\end{tabular}

$O R^{4136}$. Regression coefficient, $95 \% \mathrm{Cl}>0$ bad $/<0$ good for pain intensity ${ }^{37} *=$ Significant prognostic value. Variables that remained after the multivariate analysis shown in bold. GCPS = Graded Chronic Pain Scale. GHQ = general health questionnaire. GP = General Practioner. PCCL = Pain Coping and Cognition list. TSK = Tampa Scale of Kinesiophobia. $4 D S Q=$ Four Dimension Psychological Symptomatology Questionnaire. 
Appendix 4. Univariate level of evidence of positive association with perceived non-recovery

\begin{tabular}{|c|c|c|c|c|c|}
\hline Prognostic factors & 3 months & 6 months & 12 months & Level of Evidence & $\begin{array}{l}\text { Overall Quality of } \\
\text { Evidence }\end{array}$ \\
\hline \multicolumn{6}{|l|}{$\begin{array}{l}\text { Social demographic } \\
\text { characteristics }\end{array}$} \\
\hline $\begin{array}{l}\text { Age } \geq 40 \text { years } \\
\text { Pool et al. } \\
\text { Hoving et al. }\end{array}$ & $1.03(0.98-1.09)^{36}$ & & $2.94(1.45-5.88)^{* 37}$ & $\begin{array}{l}\text { Limited evidence for perceived non- } \\
\text { recovery at } 12 \text { months }\end{array}$ & Low \\
\hline $\begin{array}{l}\text { Age (in years) } \\
\text { Pool et al. } \\
\text { Schellingerhout et al. } \\
\end{array}$ & $1.01(0.98-1.04)^{36}$ & $0.88(0.79-0.99)^{* 40}$ & & $\begin{array}{l}\text { Limited evidence for a better outcome at } 6 \\
\text { months }\end{array}$ & Very low \\
\hline $\begin{array}{l}\text { Age-square } \\
\text { Schellingerhout et al. }\end{array}$ & & $1.00(1.00-1.06)^{* 40}$ & & $\begin{array}{l}\text { Limited evidence for perceived non- } \\
\text { recovery at } 6 \text { months }\end{array}$ & Very low \\
\hline $\begin{array}{l}\text { Gender (female) } \\
\text { Pool et al. } \\
\text { Hoving et al. } \\
\text { Vos et al. } \\
\text { Schellingerhout et al. } \\
\end{array}$ & $2.00(1.10-4.35)^{x^{36}}$ & $0.98(0.65-1.46)^{40}$ & $\begin{array}{l}\mathbf{2 . 5}(0.99-6.25)^{\star 39} \\
0.69(0.37-1.28)^{37}\end{array}$ & $\begin{array}{l}\text { Limited evidence for a better outcome at } 3 \\
\text { months }\end{array}$ & Very low \\
\hline $\begin{array}{l}\text { Level of education } \\
\quad \text { Schellingerhout et al. } \\
\text { High (ref) } \\
\text { Middle } \\
\text { Low }\end{array}$ & & $\begin{array}{l}1.26(0.79-2.02)^{40} \\
1.23(0.75-2.02)^{40}\end{array}$ & & & \\
\hline $\begin{array}{l}\text { Employment status (yes = 1) } \\
\text { Schellingerhout et al. }\end{array}$ & & $0.60(0.39-0.92)^{\star 40}$ & & $\begin{array}{l}\text { Limited evidence for a better outcome at } 6 \\
\text { months }\end{array}$ & Very low \\
\hline \multicolumn{6}{|l|}{ Symptoms } \\
\hline $\begin{array}{l}\text { Low Back Pain } \\
\text { Hoving et al. } \\
\text { Schellingerhout et al. }\end{array}$ & & $2.07(1.31-3.27)^{\star 40}$ & $2.17(1.06-4.35)^{* 31}$ & $\begin{array}{l}\text { Limited evidence for perceived non- } \\
\text { recovery at } 6 \text { and } 12 \text { months }\end{array}$ & $\begin{array}{l}\text { Low for } 6 \text { months } \\
\text { Very low for } 12 \text { months }\end{array}$ \\
\hline $\begin{array}{l}\text { Severe initial pain } \\
\text { Pool et al. } \\
\text { Vos et al. } \\
\text { Schellingerhout et al. }\end{array}$ & $1.14(0.76-1.67)^{36}$ & $0.70(0.46-1.07)^{40}$ & $1.04(0.52-2.09)^{39}$ & & \\
\hline $\begin{array}{l}\text { Severe initial pain square } \\
\text { Schellingerhout et al. }\end{array}$ & & $1.05(1.01-1.09)^{* 40}$ & & $\begin{array}{l}\text { Limited evidence for perceived non- } \\
\text { recovery at } 6 \text { months }\end{array}$ & Very low \\
\hline $\begin{array}{l}\text { Severity of complaints } \\
\text { Pool et al. }\end{array}$ & $0.95(0.75-1.22)^{36}$ & & & & \\
\hline $\begin{array}{l}\text { Duration of complaints }>2 \text { weeks } \\
\text { Vos et al. }\end{array}$ & & & $2.44(1.03-5.56)^{* 39}$ & $\begin{array}{l}\text { Limited evidence for perceived non- } \\
\text { recovery at } 12 \text { months }\end{array}$ & Very low \\
\hline $\begin{array}{l}>\text { Duration current episode } \\
\quad \text { Hoving et al. } \\
\text { Schellingerhout et al. } \\
1-3 \text { months } \\
>3 \text { months }\end{array}$ & & $\begin{array}{l}0.68(0.38-1.22)^{40} \\
1.25(0.68-2.31)^{40}\end{array}$ & $\begin{array}{l}1.14(0.53-2.44)^{37} \\
2.04(0.97-4.35)^{37}\end{array}$ & & \\
\hline $\begin{array}{l}\text { Pain in the upper part of the neck } \\
\text { Vos et al. }\end{array}$ & & & $1.64(1.22-2.17)^{x^{39}}$ & $\begin{array}{l}\text { Limited evidence for perceived non- } \\
\text { recovery at } 12 \text { months }\end{array}$ & Very low \\
\hline $\begin{array}{l}\text { Accompanying headache } \\
\text { Pool et al. } \\
\text { Hoving et al. } \\
\text { Vos et al. } \\
\text { Schellingerhout et al. }\end{array}$ & $3.45(1.41-8.33)^{+36}$ & $1.92(1.23-3.00)^{* 40}$ & $\begin{array}{l}3.33(1.35-8.33)^{+39} \\
1.37(0.69-2.70)^{37}\end{array}$ & $\begin{array}{l}\text { Limited evidence for perceived non- } \\
\text { recovery at } 3 \text { and } 6 \text { months. } \\
\text { Moderate evidence for perceived non- } \\
\text { recovery at } 12 \text { months. }\end{array}$ & Low for 3,6 and 12 months \\
\hline Radiating pain below elbow & & & $1.49(0.66-3.33)^{37}$ & & \\
\hline
\end{tabular}




\begin{tabular}{|c|c|c|c|c|c|}
\hline Hoving et al. & & & & & \\
\hline $\begin{array}{l}\text { Radiating to the back } \\
\text { Vos et al. }\end{array}$ & & & $1.45(1.09-1.92)^{* 39}$ & $\begin{array}{l}\text { Limited evidence for perceived non- } \\
\text { recovery at } 12 \text { months }\end{array}$ & Very low \\
\hline $\begin{array}{l}\text { Radiating pain (yes =1) } \\
\text { Schellingerhout et al. }\end{array}$ & & $0.66(0.45-0.97)^{* 40}$ & & $\begin{array}{l}\text { Limited evidence for a better outcome at } 6 \\
\text { months }\end{array}$ & Very low \\
\hline $\begin{array}{l}\text { No change in neck pain previous } 2 \\
\text { weeks } \\
\text { Hoving et al. }\end{array}$ & & & $2.63(1.39-4.76)^{* 37}$ & $\begin{array}{l}\text { Limited evidence for perceived non- } \\
\text { recovery at } 12 \text { months }\end{array}$ & Very low \\
\hline $\begin{array}{l}\text { Disturbed sleep due to neck pain } \\
\text { Hoving et al. }\end{array}$ & & & $0.88(0.48-1.61)^{3 /}$ & & \\
\hline $\begin{array}{l}\text { Accompanying dizziness (yes = 1) } \\
\text { Schellingerhout et al. }\end{array}$ & & $1.47(0.99-2.17)^{40}$ & & & \\
\hline $\begin{array}{l}\text { High severity of physical } \\
\text { dysfunctioning } \\
\text { Hoving et al. }\end{array}$ & & & $1.59(0.84-3.03)^{37}$ & & \\
\hline $\begin{array}{l}\text { GCPS (grade) } \\
\quad \text { Pool et al. } \\
1=\text { low intensity } \\
2=\text { high intensity } \\
3=\text { Moderately limiting } \\
4=\text { severely limiting }\end{array}$ & $\begin{array}{l}0.56(0.18-1.75)^{36} \\
1.64(0.44-6.25)^{36} \\
0.77(0.20-3.03)^{36}\end{array}$ & & & & \\
\hline $\begin{array}{l}\text { Total score on the NDI (higher score) } \\
\text { Vos et al. } \\
\text { Schellingerhout et al. }\end{array}$ & & $1.05(1.02-1.08)^{\star 40}$ & $1.08(1.01-1.14)^{* 39}$ & $\begin{array}{l}\text { Limited evidence for perceived non- } \\
\text { recovery at } 6 \text { and } 12 \text { months }\end{array}$ & Very low \\
\hline $\begin{array}{l}\text { Total score on the ALBPSQ } \\
\text { Vos et al. }\end{array}$ & & & $1.02(1.00-1.03)^{* 39}$ & $\begin{array}{l}\text { Limited evidence for perceived non- } \\
\text { recovery at } 12 \text { months }\end{array}$ & Very low \\
\hline \multicolumn{6}{|l|}{$\begin{array}{l}\text { Prior conditions/ cause } \\
\text { problem }\end{array}$} \\
\hline $\begin{array}{l}\text { Previous episodes of neck pain } \\
\text { Pool et al. } \\
\text { Hoving et al. } \\
\text { Vos et al. } \\
\text { Schellingerhout et al. } \\
\end{array}$ & $1.56(0.75-3.23)^{36}$ & $1.79(1.18-2.72)^{* 40}$ & $\begin{array}{l}1.20(1.03-1.41)^{* 39} \\
1.75(0.90-3.45)^{37}\end{array}$ & $\begin{array}{l}\text { Limited evidence for perceived non- } \\
\text { recovery at } 6 \text { months. } \\
\text { Moderate evidence for perceived non- } \\
\text { recovery at } 12 \text { months. }\end{array}$ & $\begin{array}{l}\text { Low for } 6 \text { months } \\
\text { Very low for } 12 \text { months }\end{array}$ \\
\hline $\begin{array}{l}\text { Traumatic cause } \\
\quad \text { Hoving et al. } \\
\text { Schellingerhout et al. } \\
\end{array}$ & & $1.94(1.12-3.34)^{\star 40}$ & $1.47(0.65-3.33)^{3 /}$ & $\begin{array}{l}\text { Limited evidence for perceived non- } \\
\text { recovery at } 6 \text { months }\end{array}$ & Very low \\
\hline \multicolumn{6}{|l|}{ Psychological factors } \\
\hline $\begin{array}{l}\text { Catastrophizing (PCCL) } \\
\text { Pool et al. }\end{array}$ & $1.75(0.68-4.55)^{36}$ & & & & \\
\hline $\begin{array}{l}\text { Coping (PCCL) } \\
\text { Pool et al. }\end{array}$ & $0.82(0.54-1.23)^{36}$ & & & & \\
\hline $\begin{array}{l}\text { Internal pain control (PCCL) } \\
\text { Pool et al. }\end{array}$ & $0.83(0.56-1.25)^{36}$ & & & & \\
\hline $\begin{array}{l}\text { External pain control(PCCL) } \\
\text { Pool et al. }\end{array}$ & $0.93(0.62-1.37)^{36}$ & & & & \\
\hline $\begin{array}{l}\text { TSK (higher score) } \\
\text { Pool et al. } \\
\text { Schellingerhout et al. } \\
\end{array}$ & $1.05(1.00-1.11)^{* 36}$ & $1.03(1.01-1.06)^{* 40}$ & & $\begin{array}{l}\text { Limited evidence for perceived non- } \\
\text { recovery at } 3 \text { and } 6 \text { months }\end{array}$ & $\begin{array}{l}\text { Very low for } 3 \text { months } \\
\text { Low for } 6 \text { months }\end{array}$ \\
\hline $\begin{array}{l}\text { Somatization (4DSQ) } \\
\text { Pool et al. }\end{array}$ & $1.04(0.95-1.11)^{36}$ & & & & \\
\hline $\begin{array}{l}\text { Fear (4DSQ) } \\
\text { Pool et al. }\end{array}$ & $1.27(0.81-1.96)^{36}$ & & & & \\
\hline $\begin{array}{l}\text { Distress (4DSQ) } \\
\text { Pool et al. }\end{array}$ & $1.08(0.72-1.61)^{36}$ & & & & \\
\hline $\begin{array}{l}\text { 4DSQ Depression } \\
\text { Pool et al. }\end{array}$ & $1.33(0.71-2.5)^{36}$ & & & $\begin{array}{l}\text { Limited evidence for perceived non- } \\
\text { recovery at } 3 \text { months }\end{array}$ & Very low \\
\hline
\end{tabular}

\begin{tabular}{|c|c|c|c|c|c|}
\hline \multicolumn{5}{|l|}{ General health } & \multirow[b]{2}{*}{ Very low } \\
\hline $\begin{array}{l}\text { EuroQOL VAS } \\
\text { Schellingerhout et al. }\end{array}$ & & $0.99(0.98-1.00)^{* 40}$ & & $\begin{array}{l}\text { Limited evidence for a better outcome at } 6 \\
\text { months }\end{array}$ & \\
\hline \multicolumn{3}{|l|}{ Remaining factors } & & & \\
\hline 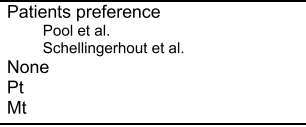 & $\begin{array}{l}\mathbf{0 . 2 5}(0.05-1.15)^{36} \\
0.58(0.69-1.45)^{36}\end{array}$ & $\begin{array}{l}0.77(0.45-1.32)^{40} \\
1.19(0.73-1.93)^{40} \\
\end{array}$ & & & \\
\hline $\begin{array}{l}\text { GP attitude } \\
\quad \text { Pool et al. } \\
\text { Purely biomedical (ref) } \\
\text { More biomedical } \\
\text { Neutral }\end{array}$ & $\begin{array}{l}2.13(0.76-5.88)^{36} \\
0.46(0.16-1.35)^{36}\end{array}$ & & & & \\
\hline $\begin{array}{l}\text { Treated for neck pain in the past (yes } \\
=1 \text { ) Schellingerhout et al. }\end{array}$ & & $1.77(1.20-2.61)^{\star 40}$ & & $\begin{array}{l}\text { Limited evidence for perceived non- } \\
\text { recovery at } 6 \text { months }\end{array}$ & Very low \\
\hline $\begin{array}{l}\text { Treated by physiotherapist before } \\
\text { Vos et al. }\end{array}$ & & & $1.25(1.10-1.89)^{*^{39}}$ & $\begin{array}{l}\text { Limited evidence for perceived non- } \\
\text { recovery at } 12 \text { months }\end{array}$ & Very low \\
\hline $\begin{array}{l}\text { Treated by manual therapist before } \\
\text { Vos et al. }\end{array}$ & & & $1.28(1.00-1.67)^{* 39}$ & $\begin{array}{l}\text { Limited evidence for perceived non- } \\
\text { recovery at } 12 \text { months }\end{array}$ & Very low \\
\hline $\begin{array}{l}\text { GP advised to wait and see } \\
\text { Vos et al. }\end{array}$ & & & $0.26(0.07-0.93)^{*^{39}}$ & $\begin{array}{l}\text { Limited evidence for a better outcome at } 12 \\
\text { months }\end{array}$ & Very low \\
\hline $\begin{array}{l}\text { GP advised to improve posture } \\
\text { Vos et al. }\end{array}$ & & & $0.96(0.72-1.28)^{39}$ & & \\
\hline $\begin{array}{l}\text { GP prescribed medication } \\
\text { Vos et al. }\end{array}$ & & & $1.64(0.81-3.33)^{39}$ & & \\
\hline $\begin{array}{l}\text { GP instructed in physical exercises } \\
\text { Vos et al. }\end{array}$ & & & $0.93(0.66-1.32)^{39}$ & & \\
\hline
\end{tabular}

Results shown in $O R=$ Odds Ratio $>1$ positive association < 1 negative associat analysis shown in bold. ALBPSQ =Acute Low Back Pain Screening Questionnaire EuroQOL = Quality of Life Scale. GCPS = Graded Chronic Pain Scale. GP = General Practioner. $N D I=$ Neck Disability Index. PCCL = Pain Coping and Cognition list. TSK = Tampa Scale of Kinesiophobia. 4DSQ = Four Dimension Psychological Symptomatology Questionnaire. 
Appendix 5. Grading assessment quality of evidence for a higher pain intensity

\begin{tabular}{|c|c|c|c|c|c|c|c|c|c|c|c|}
\hline $\begin{array}{l}\text { Prognostic factor for pain } \\
\text { intensity }\end{array}$ & $\begin{array}{l}\# \\
\text { Participants }\end{array}$ & $\begin{array}{l}\# \\
\text { Studies }\end{array}$ & Phase & $\begin{array}{l}\text { Study lim- } \\
\text { itations }\end{array}$ & Inconsistency & Indirectness & Imprecision & $\begin{array}{l}\text { Publication } \\
\text { bias }\end{array}$ & $\begin{array}{l}\text { Moderate/large } \\
\text { effect size }\end{array}$ & $\begin{array}{l}\text { Dose } \\
\text { effect }\end{array}$ & $\begin{array}{l}\text { Overall } \\
\text { quality }\end{array}$ \\
\hline Age & 1542 & 2 & 1 & $\mathrm{X}$ & $\checkmark$ & $\checkmark$ & $\checkmark$ & $\mathrm{X}$ & $\checkmark$ & $\mathrm{X}$ & ++ \\
\hline Gender (female) & 146 & 1 & 1 & $\mathrm{X}$ & $\mathrm{X}$ & $\checkmark$ & $\mathrm{X}$ & $\mathrm{X}$ & $\mathrm{X}$ & $\mathrm{X}$ & + \\
\hline Non-working & 1359 & 1 & 1 & $\mathrm{X}$ & $\mathrm{X}$ & $\checkmark$ & $\mathrm{X}$ & $\mathrm{X}$ & $\mathrm{X}$ & $\mathrm{X}$ & + \\
\hline Low Back Pain & 1542 & 2 & 1 & $\mathrm{X}$ & $\checkmark$ & $\checkmark$ & $\checkmark$ & $\mathrm{X}$ & $\mathrm{X}$ & $\mathrm{X}$ & + \\
\hline Pain intensity & 183 & 1 & 1 & $\mathrm{X}$ & $\mathrm{X}$ & $\checkmark$ & $\mathrm{X}$ & $\mathrm{X}$ & $\checkmark$ & $\mathrm{X}$ & + \\
\hline Severity of complaints & 146 & 1 & 1 & $\mathrm{X}$ & $\mathrm{X}$ & $\checkmark$ & $\mathrm{X}$ & $\mathrm{X}$ & $\mathrm{X}$ & $\mathrm{X}$ & + \\
\hline Duration neck pain & 183 & 1 & 1 & $\mathrm{X}$ & $\mathrm{X}$ & $\checkmark$ & $\mathrm{X}$ & $\mathrm{X}$ & $\mathrm{X}$ & $\mathrm{X}$ & + \\
\hline Previous episodes neck pain & 183 & 1 & 1 & $\mathrm{X}$ & $\mathrm{X}$ & $\checkmark$ & & $\mathrm{X}$ & $\mathrm{X}$ & $\mathrm{X}$ & + \\
\hline Neck injury & 1542 & 2 & 1 & $\mathrm{X}$ & $\checkmark$ & $\checkmark$ & $\checkmark$ & $\mathrm{X}$ & $\mathrm{X}$ & $\mathrm{X}$ & + \\
\hline Lifting in last job & 1359 & 1 & 1 & $\mathrm{X}$ & $\mathrm{X}$ & $\checkmark$ & $\mathrm{X}$ & $\mathrm{X}$ & $\mathrm{X}$ & $\mathrm{X}$ & + \\
\hline Gardening & 1359 & 1 & 1 & $\mathrm{X}$ & $\mathrm{X}$ & $\checkmark$ & $\mathrm{X}$ & $\mathrm{X}$ & $\mathrm{X}$ & $\mathrm{X}$ & + \\
\hline Cycling & 1359 & 1 & 1 & $\mathrm{X}$ & $\mathrm{X}$ & $\checkmark$ & $\mathrm{X}$ & $\mathrm{X}$ & $\mathrm{X}$ & $\mathrm{X}$ & + \\
\hline Physical activity & 1359 & 1 & 1 & $\mathrm{X}$ & $\mathrm{X}$ & $\checkmark$ & $\mathrm{X}$ & $\mathrm{X}$ & $\mathrm{X}$ & $\mathrm{X}$ & + \\
\hline TSK (higher score) & 146 & 1 & 1 & $\mathrm{X}$ & $\mathrm{X}$ & $\checkmark$ & $\mathrm{X}$ & $\mathrm{X}$ & $\mathrm{X}$ & $\mathrm{X}$ & + \\
\hline Somatisation & 146 & 1 & 1 & $\mathrm{X}$ & $\mathrm{X}$ & $\checkmark$ & $\mathrm{X}$ & $\mathrm{X}$ & $\mathrm{X}$ & $\mathrm{X}$ & + \\
\hline Fear & 146 & 1 & 1 & $\mathrm{X}$ & $\mathrm{X}$ & $\checkmark$ & $\mathrm{X}$ & $\mathrm{X}$ & $\mathrm{X}$ & $\mathrm{X}$ & + \\
\hline Alcohol intake & 1359 & 1 & 1 & $\mathrm{X}$ & $\mathrm{X}$ & $\checkmark$ & $\mathrm{X}$ & $\mathrm{X}$ & $\mathrm{X}$ & $\mathrm{X}$ & + \\
\hline Perceived General Health & 1359 & 1 & 1 & $\mathrm{X}$ & $\mathrm{X}$ & $\checkmark$ & $X$ & $\mathrm{X}$ & $\mathrm{X}$ & $\mathrm{X}$ & + \\
\hline $\begin{array}{l}\text { GHQ (higher score, poor ps- } \\
\text { ychological health }\end{array}$ & 1359 & 1 & 1 & $X$ & $\mathrm{X}$ & $\checkmark$ & $X$ & $\mathrm{X}$ & X & $\mathrm{X}$ & + \\
\hline
\end{tabular}

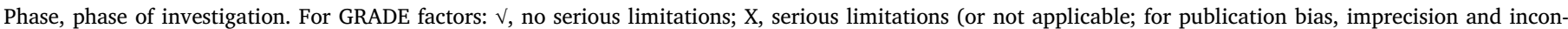

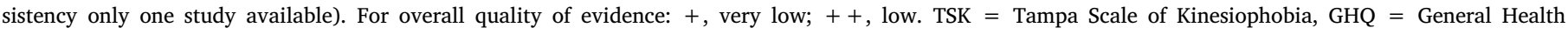
Questionnaire.

Appendix 6. Grading assessment quality of evidence for the outcome variable perceived non-recovery

\begin{tabular}{|c|c|c|c|c|c|c|c|c|c|c|c|}
\hline $\begin{array}{l}\text { Prognostic factor for per- } \\
\text { ceived non-recovery }\end{array}$ & $\begin{array}{l}\# \\
\text { Participants }\end{array}$ & $\begin{array}{l}\# \\
\text { Studies }\end{array}$ & Phase & $\begin{array}{l}\text { Study lim- } \\
\text { itations }\end{array}$ & Inconsistency & Indirectness & Imprecision & $\begin{array}{l}\text { Publication } \\
\text { bias }\end{array}$ & $\begin{array}{l}\text { Moderate/large } \\
\text { effect size }\end{array}$ & $\begin{array}{l}\text { Dose } \\
\text { effect }\end{array}$ & $\begin{array}{l}\text { Overall } \\
\text { quality }\end{array}$ \\
\hline Age $\geq 40$ & 183 & 1 & 1 & $\mathrm{X}$ & $\mathrm{X}$ & $\checkmark$ & $\mathrm{X}$ & $\mathrm{X}$ & $\checkmark$ & $\mathrm{X}$ & + \\
\hline Age (years) & 468 & 1 & 3 & $\mathrm{X}$ & $\mathrm{X}$ & $\checkmark$ & $\mathrm{X}$ & $\mathrm{X}$ & $\mathrm{X}$ & $\mathrm{X}$ & + \\
\hline Age-square & 468 & 1 & 3 & $\mathrm{X}$ & $\mathrm{X}$ & $\checkmark$ & $\mathrm{X}$ & $\mathrm{X}$ & $\mathrm{X}$ & $\mathrm{X}$ & + \\
\hline Gender & 146 & 1 & 1 & $\mathrm{X}$ & $\mathrm{X}$ & $\checkmark$ & $\mathrm{X}$ & $\mathrm{X}$ & $\mathrm{X}$ & $\mathrm{X}$ & + \\
\hline $\begin{array}{l}\text { Employment status } \\
\quad(\text { yes }=1)\end{array}$ & 468 & 1 & 3 & $\mathrm{X}$ & $\mathrm{X}$ & $\checkmark$ & $\mathrm{X}$ & $\mathrm{X}$ & $\mathrm{X}$ & $\mathrm{X}$ & + \\
\hline \multicolumn{12}{|l|}{ Low Back Pain } \\
\hline 6 months & 468 & 1 & 3 & $\mathrm{X}$ & $\checkmark$ & $\checkmark$ & $\checkmark$ & $\mathrm{X}$ & $\mathrm{X}$ & $\mathrm{X}$ & ++ \\
\hline 12 months & 183 & 1 & 1 & $\mathrm{X}$ & $\checkmark$ & $\checkmark$ & $\checkmark$ & $\mathrm{X}$ & $\mathrm{X}$ & $\mathrm{X}$ & + \\
\hline Severe initial pain square & 468 & 1 & 3 & $\mathrm{X}$ & $\mathrm{X}$ & $\checkmark$ & $\mathrm{X}$ & $\mathrm{X}$ & $\mathrm{X}$ & $\mathrm{X}$ & + \\
\hline $\begin{array}{l}\text { Duration neck pain } \geq 2 \text { we- } \\
\quad \text { eks }\end{array}$ & 187 & 1 & 1 & $\mathrm{X}$ & $\mathrm{X}$ & $\checkmark$ & $\mathrm{X}$ & $\mathrm{X}$ & $\mathrm{X}$ & $\mathrm{X}$ & + \\
\hline \multicolumn{12}{|l|}{ Accompanying headache } \\
\hline 3 months & 146 & 1 & 1 & $\mathrm{X}$ & $\checkmark$ & $\checkmark$ & $\checkmark$ & $\mathrm{X}$ & $\checkmark$ & $\mathrm{X}$ & ++ \\
\hline 6 months & 468 & 1 & 3 & $\mathrm{X}$ & $\checkmark$ & $\checkmark$ & $\checkmark$ & $\mathrm{X}$ & $\mathrm{X}$ & $\mathrm{X}$ & ++ \\
\hline 12 months & 370 & 2 & 1 & $\mathrm{X}$ & $\checkmark$ & $\checkmark$ & $\checkmark$ & $\mathrm{X}$ & $\checkmark$ & $\mathrm{X}$ & ++ \\
\hline Radiating to the back & 187 & 1 & 1 & $\mathrm{X}$ & $\mathrm{X}$ & $\checkmark$ & $\mathrm{X}$ & $\mathrm{X}$ & $\mathrm{X}$ & $\mathrm{X}$ & + \\
\hline Radiating pain (yes $=1$ ) & 468 & 1 & 3 & $\mathrm{X}$ & $\mathrm{X}$ & $\checkmark$ & $\mathrm{X}$ & $\mathrm{X}$ & $\mathrm{X}$ & $\mathrm{X}$ & + \\
\hline $\begin{array}{l}\text { No change in neckpain pre- } \\
\text { vious } 2 \text { weeks }\end{array}$ & 183 & 1 & 1 & $\mathrm{X}$ & $\mathrm{X}$ & $\checkmark$ & $\mathrm{X}$ & $\mathrm{X}$ & $\checkmark$ & $\mathrm{X}$ & + \\
\hline \multicolumn{12}{|c|}{ Total score on the NDI (higher score) } \\
\hline 6 months & 468 & 10 & 3 & $\mathrm{X}$ & $\mathrm{X}$ & $\checkmark$ & $\mathrm{X}$ & $\mathrm{X}$ & $\mathrm{X}$ & $\mathrm{X}$ & + \\
\hline 12 months & 187 & 1 & 1 & $\mathrm{X}$ & $\mathrm{X}$ & $\checkmark$ & $\mathrm{X}$ & $\mathrm{X}$ & $\mathrm{X}$ & $\mathrm{X}$ & + \\
\hline Total score on the ALBPSQ & 187 & 1 & 1 & $\mathrm{X}$ & $\mathrm{X}$ & $\checkmark$ & $\mathrm{X}$ & $\mathrm{X}$ & $\mathrm{X}$ & $\mathrm{X}$ & + \\
\hline \multicolumn{12}{|c|}{ Previous episodes of neck pain } \\
\hline 6 months & 468 & 1 & 3 & $\mathrm{X}$ & $\checkmark$ & $\checkmark$ & $\checkmark$ & $\mathrm{X}$ & $\mathrm{X}$ & $\mathrm{X}$ & ++ \\
\hline 12 months & 370 & 2 & 1 & $\mathrm{X}$ & $\checkmark$ & $\checkmark$ & $\checkmark$ & $\mathrm{X}$ & $\mathrm{X}$ & $\mathrm{X}$ & + \\
\hline Traumatic cause & 468 & 1 & 3 & $\mathrm{X}$ & $\mathrm{X}$ & $\checkmark$ & $\mathrm{X}$ & $\mathrm{X}$ & $\mathrm{X}$ & $\mathrm{X}$ & + \\
\hline \multicolumn{12}{|l|}{ TSK (higher score) } \\
\hline 3 months & 146 & 1 & 1 & $\mathrm{X}$ & $\checkmark$ & $\checkmark$ & $\mathrm{X}$ & $\mathrm{X}$ & $\mathrm{X}$ & $\mathrm{X}$ & + \\
\hline 6 months & 468 & 1 & 3 & $\mathrm{X}$ & $\checkmark$ & $\checkmark$ & $\mathrm{X}$ & $\mathrm{X}$ & $\mathrm{X}$ & $\mathrm{X}$ & ++ \\
\hline Depression (4DSQ) & 146 & 1 & 1 & $\mathrm{X}$ & $\mathrm{X}$ & $\checkmark$ & $\mathrm{X}$ & $\mathrm{X}$ & $\mathrm{X}$ & $\mathrm{X}$ & + \\
\hline EuroQOL VAS & 468 & 1 & 3 & $\mathrm{X}$ & $\mathrm{X}$ & $\checkmark$ & $\mathrm{X}$ & $\mathrm{X}$ & $\mathrm{X}$ & $\mathrm{X}$ & + \\
\hline Treated for neck pain in past & 468 & 1 & 3 & $\mathrm{X}$ & $\mathrm{X}$ & $\checkmark$ & $\mathrm{X}$ & $\mathrm{X}$ & $\mathrm{X}$ & $\mathrm{X}$ & + \\
\hline Treated by physio before & 187 & 1 & 1 & $\mathrm{X}$ & $\mathrm{X}$ & $\checkmark$ & $\mathrm{X}$ & $\mathrm{X}$ & $\mathrm{X}$ & $\mathrm{X}$ & + \\
\hline Treated by MT before & 187 & 1 & 1 & $\mathrm{X}$ & $\mathrm{X}$ & $\checkmark$ & $\mathrm{X}$ & $\mathrm{X}$ & $\mathrm{X}$ & $\mathrm{X}$ & + \\
\hline GP wait and see advise & 187 & 1 & 1 & $\mathrm{X}$ & $\mathrm{X}$ & $\checkmark$ & $\mathrm{X}$ & $\mathrm{X}$ & $\checkmark$ & $\mathrm{X}$ & + \\
\hline
\end{tabular}

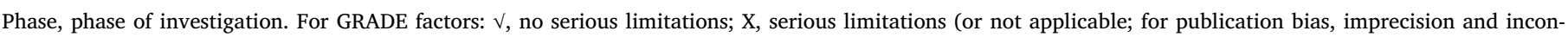

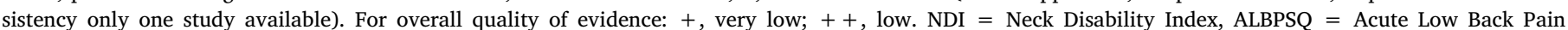




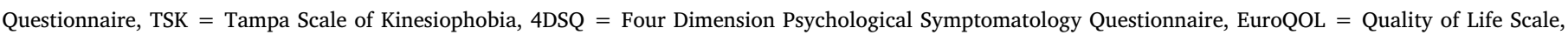
$\mathrm{GP}=$ General Practioner.

Appendix 7. Reviewer agreement for full text screening after screening title and abstract

(1) Kjellman G, Öberg B, Hensing G, Alexanderson K. A 12-year follow-up of subjects initially sicklisted with neck/shoulder or low back diagnoses. Physiother Res Int. 1358-2267 2001 03; 6 (1):52-63 12p.

(2) Ailliet L, Rubinstein SM, Hoekstra T, van Tulder MW, de Vet HC. Adding Psychosocial Factors Does Not Improve Predictive Models for People With Spinal Pain Enough to Warrant Extensive Screening for Them at Baseline. Phys Ther. 1538-6724; 0031-9023 2016 Feb 4'

(3) P, Cassidy JD, Carroll LJ, Kristman V. The annual incidence and course of neck pain in the general population: A population-based cohort study. Pain. 0304-3959 2004; 112 (3):267-273.

(4) Pool JJ, Ostelo RW, Knol D, Bouter LM, de Vet HC. Are psychological factors prognostic indicators of outcome in patients with sub-acute neck pain?, Man Ther. 1532-2769; 1356-689X 2010 Feb; 15 (1):111-116.

(5) Vos CJ, Verhagen AP, Passchier J, Koes BW. Clinical course and prognostic factors in acute neck pain: An inception cohort study in general practice. Pain Med (USA). 1526-2375; 1526-4637 2008; 9 (5):572-580.

(6) Badcock LJ, Lewis M, Hay EM, Croft PR. Consultation and the Outcome of Shoulder-Neck Pain: A Cohort Study in the Population. J Rheumatol. 0315-162X 2003; 30 (12):2694-2699.

(7) Johansen JB, Røe C, Bakke ES, Mengshoel AM, Storheim K, Andelic N. The determinants of function and disability in neck patients referred to a specialized outpatient clinic. Clin J Pain. 0749-8047 2013 2013; 29 (12):1029-1035 7p.

(8) Paksaichol A, Janwantanakul P, Lawsirirat C. Development of a Neck Pain Risk Score for Predicting Nonspecific Neck Pain with Disability in Office Workers: a 1-Year Prospective Cohort Study. J Manipulative Physiol Ther. 0161-4754 2014 09; 37 (7):468-475 8p.

(9) Boersma K, Linton SJ. Expectancy, fear and pain in the prediction of chronic pain and disability: A prospective analysis. Eur J Pain. 1090-3801; 1532-2149 2006; 10 (6):551-557.

(10) Hurwitz EL, Goldstein MS, Morgenstern H, Chiang L. The impact of psychosocial factors on neck pain and disability outcomes among primary care patients: results from the UCLA Neck Pain Study. Disabil Rehabil. 0963-8288 2006 11/15; 28 (21):1319-1329 11p.

(11) Wirth B, Humphreys BK, Peterson C. Importance of psychological factors for the recovery from a first episode of acute non-specific neck pain - a longitudinal observational study. CHIROPRACT MANUAL THER. 2045-709X 2016 03/16; 24:1-10 10p.

(12) Mercado AC, Carroll LJ, Cassidy JD, Cote P. Passive coping is a risk factor for disabling neck or low back pain. Pain. Sep 2005; 117 (1-2):51-57.

(13) Kovacs FM, Seco J, Royuela A, Melis S, Sánchez C, Díaz-Arribas MJ et al. Patients with neck pain are less likely to improve if they experience poor sleep quality: a prospective study in routine practice. Clin J Pain. 0749-8047 2015 08; 31 (8):713-721 9p.

(14) Leaver AM, Maher CG, McAuley JH, Jull G, Latimer J, Refshauge KM. People seeking treatment for a new episode of neck pain typically have rapid improvement in symptoms: an observational study. J Physiother (ELSEVIER) 1836-9553 2013 03; 59 (1):31-37 7p.

(15) Hill J, Lewis M, Papageorgiou AC, Dziedzic K, Croft P. Predicting persistent neck pain: a 1-year follow-up of a population cohort. Spine. 0362-2436 2004 08; 29 (15):1648-1654 7p.

(16) Dagfinrud H, Storheim K, Magnussen LH, Ødegaard T, Hoftaniska I, Larsen LG et al. The predictive validity of the Örebro Musculoskeletal Pain Questionnaire and the clinicians' prognostic assessment following manual therapy treatment of patients with LBP and neck pain. MANUAL THER.1356-689X 2013 04; 18 (2):124-129 6p.

(17) Grooten WJA. Predictors for persistent neck/shoulder pain, medical care-seeking due to neck/shoulder pain and sickness absence. Clin Rehabil. 0269-2155 2007 07; 21 (7):648-659 12p.

(18) Webb R, Brammah T, Lunt M, Urwin M, Allison T, Symmons D. Prevalence and predictors of intense, chronic, and disabling neck and back pain in the UK general population. Spine. 0362-2436 2003 06; 28 (11):1195-1202 8p.

(19) Hoving JL, De Vet HCW, Twisk JWR, Devillã WLJM, Van DW, Koes BW et al. Prognostic factors for neck pain in general practice. Pain. 0304-3959 2004; 110 (3):639-645.

(20) Kjellman G, Skargren E, Â-berg B., Prognostic factors for perceived pain and function at one-year follow-up in primary care patients with neck pain. Disabil Rehabil. 0963-8288 2002; 24 (7):364-370.

(21) Hellsing AL, Linton SJ, Kalvemark M. A prospective study of patients with acute back and neck pain in Sweden. Phys Ther. $0031-9023$ 1994 1994; 74 (2):116-128 13p.

(22) Keijsers E, Feleus A, Miedema HS, Koes BW, Bierma-Zeinstra SM. Psychosocial factors predicted nonrecovery in both specific and nonspecific diagnoses at arm, neck, and shoulder. J Clin Epidemiol. 1878-5921; 0895-4356 2010 Dec; 63 (12):1370-1379.

(23) Shahidi B, CurranEverett D, Maluf KS. Psychosocial, physical, and neurophysiological risk factors for chronic neck pain: A prospective inception cohort study. The Journal of Pain. 2015.

(24) Croft PR, Lewis M, Papageorgiou AC, Thomas E, Jayson MIV, Macfarlane GJ et al. Risk factors for neck pain: A longitudinal study in the general population. Pain. 0304-3959 2001; 93 (3):317-325.

(25) Christensen JO, Knardahl S. Time-course of occupational psychological and social factors as predictors of new-onset and persistent neck pain: A three-wave prospective study over 4 years. Pain. 0304-3959 2014 07; 155 (7):1262-1271.

\section{Appendix A. Supplementary data}

Supplementary data to this article can be found online at https://doi.org/10.1016/j.msksp.2019.03.009.

\section{Funding}

This research was supported by the Institute of Movement studies. Did not receive any specific grant from funding agencies in the public, commercial, or not-for-profit sectors. 


\section{References}

Adolfsson, J., Steineck, G., 2000. Prognostic and treatment- predictive factors $Đ$ is there a difference? Nature 3, 265-268.

Akobeng, A.K., 2016. Understanding type I and type II errors, statistical power and sample size. Acta Paediatr. 105 (6), 605-609. https://doi.org/10.1111/apa.13384.

Anstey, R., Kongsted, A., Kamper, S., Hancock, M.J., 2016. Are people with whiplashassociated neck pain different from people with nonspecific neck pain? J. Orthop. Sport. Phys. Ther. 46 (10), 894-901. https://doi.org/10.2519/jospt.2016.6588.

Artus, M., Campbell, P., Mallen, C.D., Dunn, K.M., Van Der Windt, D.A.W., 2017. Generic prognostic factors for musculoskeletal pain in primary care: a systematic review. BMJ Open 7. https://doi.org/10.1136/.

Balshem, H., Helfand, M., Sch, H.J., et al., 2011. GRADE Guidelines: 3, vol. 64 Rating the quality of evidencehttps://doi.org/10.1016/j.jclinepi.2010.07.015.

Bertozzi, L., Gardenghi, I., Turoni, F., et al., 2013. Effect of therapeutic exercise on pain and disability in the management of chronic nonspecific neck pain: systematic review and meta-analysis of randomized trials. Phys. Ther. 93 (8), 1026-1036. https:// watermark.silverchair.com/ptj1026.pdf?token = AQECAHi208BE49Ooan9kkhW_ Ercy7Dm3ZL

9Cf3qfKAc485ysgAAAbcwggGzBgkqhkiG9w0BBwagggGkMIIBoAIBADCCAZkGCSqG SIb3DQEHATAeBglghkgBZQMEAS4wEQQM-tWbQKw0EcXQ8dbzAgEQgIIBalnDV1 s6921Nkdbx9suX7dKMAvGrI06WDXmuaSf623UWW3, Accessed date: 14 February 2018.

Bérubé, M., Gélinas, C., Choinière, M., et al., 2017. The effect of psychological interventions on the prevention of chronic pain in adults: a systematic review protocol. Syst. Rev. https://doi.org/10.1186/s13643-017-0583-7.

Bier, J.D., Ostelo, R.W.J.G., van Hooff, M.L., Koes, B.W., Verhagen, A.P., 2017. Validity and reproducibility of the STarT back tool (Dutch version) in patients with low back pain in primary care settings. Phys. Ther. 97 (5), 561-570. https://doi.org/10.1093/ $\mathrm{ptj} / \mathrm{pzx} 023$.

Bovim, G., Schrader, H., Sand, T., 1994. Neck pain in the general population. Spine 19 (12), 1307-1309. https://doi.org/10.1097/00007632-199406000-00001. (Phila Pa 1976)

Bromley Milton, M., Börsbo, B., Rovner, G., Lundgren-Nilsson, Å., Stibrant-Sunnerhagen, K., Gerdle, B., 2013. Is pain intensity really that important to assess in chronic pain patients? A study based on the Swedish quality Registry for pain rehabilitation (SQRP). PLoS One 8 (6). https://doi.org/10.1371/journal.pone.0065483.

Campbell, L., Smith, A., McGregor, L., Sterling, M., 2018. Psychological factors and the development of chronic whiplash associated disorder(s). Clin. J. Pain 34 (8), 1. https://doi.org/10.1097/AJP.0000000000000597.

Casarett, D., Karlawish, J., Sankar, P., 2001. Designing pain research from the patient's perspective. What 2 (4).

Childs, J.D., Cleland, J.A., Elliott, J.M., et al., 2008. Neck Pain: clinical practice guidelines linked to the international classification of functioning, disability, and health from the orthopedic section of the american physical therapy association. J. Orthop. Sport. Phys. Ther. 38 (9), A1-A34. https://doi.org/10.2519/jospt.2008.0303.

Clark, G.M., 2008. Prognostic factors versus predictive factors: examples from a clinical trial of erlotinib. Mol. Oncol. 1, 406-412. https://doi.org/10.1016/j.molonc.2007. 12.001.

Côté, P., Cassidy, D.J., Carroll, L.J., Kristman, V., 2004. The annual incidence and course of neck pain in the general population: a population-based cohort study. Pain 112 (3), 267-273. https://doi.org/10.1016/j.pain.2004.09.004.

Croft, P.R., Lewis, M., Papageorgiou, A.C., et al., 2001. Risk factors for neck pain: a longitudinal study in the general population. Pain 93 (3), 317-325. http://www.ncbi. nlm.nih.gov/pubmed/11514090, Accessed date: 14 February 2018.

GBD 2015 Disease and Injury Incidence and Prevalence Collaborators G 2015 D and II and P. Global, regional, and national incidence, prevalence, and years lived with disability for 310 diseases and injuries, 1990-2015: a systematic analysis for the Global Burden of Disease Study 2015. Lancet (London, England) 388 (10053), 1545-1602. https://doi.org/10.1016/S0140-6736(16)31678-6.

Geneen, L.J.S.B., Andrew Moore, R., Clarke, C., Martin, D., Colvin, L.A., Smith, B.H., 2017. Cochrane Database of Systematic Reviews Physical activity and exercise for chronic pain in adults: an overview of Cochrane Reviews (Review) Physical activity and exercise for chronic pain in adults: an overview of Cochrane Reviews (Review) $\mathrm{i}$ Physical acti. Cochrane Database Syst. Rev. 4. https://doi.org/10.1002/14651858. CD011279.pub3.

George, S.Z., Beneciuk, J.M., 2015. Psychological predictors of recovery from low back pain: a prospective study. BMC Muscoskelet. Disord. 16 (1), 1-7. https://doi.org/10. 1186/s12891-015-0509-2.

Gewandter, J.S., Dworkin, R.H., Turk, D.C., et al., 2015. Research design considerations for chronic pain prevention clinical trials: IMMPACT recommendations HHS Public Access. Pain 156 (7), 1184-1197. https://doi.org/10.1097/j.pain. 0000000000000191.

Gross, A., Langevin, P., Burnie, S.J., et al., 2015. Manipulation and mobilisation for neck pain contrasted against an inactive control or another active treatment. Cochrane Database Syst. Rev. 23 (9). https://doi.org/10.1002/14651858.CD004249.pub4.

Hancock, M., Herbert, R.D., Maher, C.G., 2009. A guide to interpretation of studies investigating subgroups of responders to physical therapy interventions. Phys. Ther. 89 (7), 698-704. https://doi.org/10.2522/ptj.20080351.

Hayden, J.A., van der Windt, D.A., Cartwright, J.L., Côté, P., Bombardier, C., 2013. Assessing bias in studies of prognostic factors. Ann. Intern. Med. 158 (4), 280. https://doi.org/10.7326/0003-4819-158-4-201302190-00009.

Hayden, J.A., Tougas, M.E., Riley, R., Iles, R., Pincus, T., 2014. Individual recovery expectations and prognosis of outcomes in non-specific low back pain: prognostic factor exemplar review. Cochrane Database Syst. Rev. https://doi.org/10.1002/14651858. CD011284.

Hill, J., Lewis, M., Papageorgiou, A.C., Dziedzic, K., Croft, P., 2004. Predicting persistent neck pain: a 1-year follow-up of a population cohort. Spine 29 (15), 1648-1654. https://doi.org/10.1097/01.BRS.0000132307.06321.3C. (Phila Pa 1976).

Hoving, J.L., De Vet, H.C.W., Twisk, J.W.R., et al., 2004. Prognostic factors for neck pain in general practice. Pain 110, 639-645. https://doi.org/10.1016/j.pain.2004.05.002.

Hoy, D., Geere, J.-A., Davatchi, F., Meggitt, B., Barrero, L.H., 2014. A time for action: opportunities for preventing the growing burden and disability from musculoskeletal conditions in low- and middle-income countries. Best Pract. Res. Clin. Rheumatol. 28 (3), 377-393. https://doi.org/10.1016/j.berh.2014.07.006.

Huguet, A., Hayden, J.A., Stinson, J., et al., 2013. Judging the quality of evidence in reviews of prognostic factor research: adapting the GRADE framework. Syst. Rev. 2 (1), 1. https://doi.org/10.1186/2046-4053-2-71.

Hush, J.M., Lin, C.C., Michaleff, Z.A., Verhagen, A., Refshauge, K.M., 2011. Prognosis of acute idiopathic neck pain is poor: a systematic review and meta-analysis. YAPMR 92, 824-829. https://doi.org/10.1016/j.apmr.2010.12.025.

Kelly, J., Ritchie, C., Sterling, M., 2017. Clinical prediction rules for prognosis and treatment prescription in neck pain: a systematic review. Musculoskelet Sci. Pract. 27, 155-164. https://doi.org/10.1016/j.math.2016.10.066.

Koppes, D., 2016. Zorg voor de fysiotherapeut - top-10 gezondheidsproblemen (DCSPH) Nivel. Accessed 7. http://www.nivel.nl/node/4677.

Landers, M.R., Creger, R.V., Baker, C.V., Stutelberg, K.S., 2008. The use of fear-avoidance beliefs and nonorganic signs in predicting prolonged disability in patients with neck pain. Man. Ther. 13 (3), 239-248. https://doi.org/10.1016/j.math.2007.01.010.

Leaver, A.M., Maher, C.G., McAuley, J.H., Jull, G., Latimer, J., Refshauge, K.M., 2013. People seeking treatment for a new episode of neck pain typically have rapid improvement in symptoms: an observational study. J. Physiother. https://doi.org/10. 1016/S1836-9553(13)70144-9.

Lee, H., Hi $i^{1 / 2}$ bscher, M., Moseley, G.L., et al., 2015. How does pain lead to disability? A systematic review and meta-analysis of mediation studies in people with back and neck pain. Pain. https://doi.org/10.1097/j.pain.0000000000000146.

Mallen, C.D., Peat, G., Thomas, E., Dunn, K.M., Croft, P.R., 2007. Prognostic factors for musculoskeletal pain in primary care: a systematic review. Br. J. Gen. Pract. 57 (541), 655-661. http://www.ncbi.nlm.nih.gov/pubmed/17688762, Accessed date: 14 February 2018.

Moher, D., Liberati, A., Tetzlaff, J., Altman, D.G., PRISMA Group, T., 2009. Preferred reporting items for systematic reviews and meta-analyses: the PRISMA statement. J. Clin. Epidemiol. 62, 1006-1012. https://doi.org/10.1016/j.jclinepi.2009.06.005.

Nicholas, M.K., Linton, S.J., Watson, P.J., Main, C.J., 2011. Early identification and management of psychological risk factors ("Yellow flags") in patients with low back pain: a reappraisal. Phys. Ther. 91 (5), 737-753. https://doi.org/10.2522/ptj. 20100224.

Ortego, G., Villafañe, J.H., Doménech-García, V., Berjano, P., Bertozzi, L., Herrero, P., 2016. Is there a relationship between psychological stress or anxiety and chronic nonspecific neck-arm pain in adults? A systematic review and meta-analysis. J. Psychosom. Res. 90, 70-81. https://doi.org/10.1016/j.jpsychores.2016.09.006.

Pierik, J., IJzerman, M., Gaakeer, M., et al., 2015. Incidence and Prognostic Factors of Chronic Pain after Isolated Musculoskeletal Extremity Injury. https://doi.org/10. 1002/ejp.796.

Pincus, T., Kim Burton, A., Vogel, S., Field, A.P., 2002. A Systematic Review of Psychological Factors as Predictors of Chronicity/Disability in Prospective Cohorts of Low Back Pain, vol. 27.

Pool, J.J.M., Ostelo, R.W.J.G., Knol, D., Bouter, L.M., De Vet, H.C.W., 2010. Are psychological factors prognostic indicators of outcome in patients with sub-acute neck pain? Man. Ther. 15, 111-116. https://doi.org/10.1016/j.math.2009.08.001.

Reid, K.J., Harker, J., Bala, M.M., et al., 2011. Epidemiology of chronic non-cancer pain in Europe: narrative review of prevalence, pain treatments and pain impact. Curr. Med. Res. Opin. 27 (2), 449-462. https://doi.org/10.1185/03007995.2010.545813.

Riley, R.D., Hayden, J.A., Steyerberg, E.W., et al., 2013. Guidelines and guidance prognosis research strategy (PROGRESS) 2: prognostic factor research. PLoS Med. 10 (2), e1001380. https://doi.org/10.1371/journal.pmed.1001380.

Ris, I., Juul-Kristensen, B., Boyle, E., Kongsted, A., Manniche, C., Søgaard, K., 2017. Chronic neck pain patients with traumatic or non-traumatic onset: differences in characteristics. A cross-sectional study. Scand J. Pain 14, 1-8. https://doi.org/10. 1016/j.sjpain.2016.08.008.

Sanderson, T., Morris, M., Calnan, M., Richards, P., Hewlett, S., 2010. UKPMC funders group patient perspective of measuring treatment efficacy: the rheumatoid arthritis patient priorities for pharmacological interventions ( RAPP-PI ) outcomes. Arthritis Rheum. 62 (5), 647-656. https://doi.org/10.1002/acr.20151.Patient.

Schellingerhout, J.M., Heymans, M.W., Verhagen, A.P., Lewis, M., De Vet, H.C.W., Koes, B.W., 2010. Prognosis of patients with nonspecific neck pain development and external validation of a prediction rule for persistence of complaints. Spine 35 (17), 827-835. (Phila Pa 1976). https://insights.ovid.com/pubmed?pmid=20628331, Accessed date: 14 February 2018.

Stenneberg, M.S., Rood, M., de Bie, R., Schmitt, M.A., Cattrysse, E., Scholten-Peeters, G.G., 2017. To what degree does active cervical range of motion differ between patients with neck pain, patients with whiplash, and those without neck pain? A systematic review and meta-analysis. Arch. Phys. Med. Rehabil. 98 (7), 1407-1434. https://doi.org/10.1016/j.apmr.2016.10.003.

Struyf, F. b, Geraets, J., Noten, S. b, Meeus, M. b d, Nijs, J. e f., 2016. A multivariable prediction model for the chronification of non-traumatic shoulder pain: a systematic review. Pain Physician 19 (2), 1-10. https://doi.org/10.1017/CBO9781107415324. 004.

Thompson, D.P., Urmston, M., Oldham, J.A., Woby, S.R., 2010. The association between 
cognitive factors, pain and disability in patients with idiopathic chronic neck pain. Disabil. Rehabil. 32 (21), 1758-1767. https://doi.org/10.3109/ 09638281003734342.

Traeger, A.C., Henschke, N., Hübscher, M., et al., 2016. Estimating the risk of chronic pain: development and validation of a prognostic model (PICKUP) for patients with acute low back pain. PLoS Med. https://doi.org/10.1371/journal.pmed.1002019.

Treede, R.-D., Rief, W., Barke, A., et al., 2015. A classification of chronic pain for ICD-11. Pain 156 (6), 1003-1007. https://doi.org/10.1097/j.pain.0000000000000160.

Verhagen, A.P., Lewis, M., Schellingerhout, J.M., et al., 2011. Do whiplash patients differ from other patients with non-specific neck pain regarding pain, function or prognosis? Man. Ther. 16 (5), 456-462. https://doi.org/10.1016/j.math.2011.02.009.

Vonk, F., Verhagen, A.P., Twisk, J.W., Köke, A.J.A., Luiten, M.W.C.T., Koes, B.W., 2009. Effectiveness of a behaviour graded activity program versus conventional exercise for chronic neck pain patients. Eur. J. Pain 13 (5), 533-541. https://doi.org/10.1016/j. ejpain.2008.06.008.

Vos, C.J., Verhagen, A.P., Passchier, J., Koes, B.W., 2008. Clinical course and prognostic factors in acute neck pain: an inception cohort study in general practice. Pain Med. 9 (5), 572-580. https://doi.org/10.1111/j.1526-4637.2008.00456.x.

Walton, D.M., 2013. An overview of systematic reviews on prognostic factors in neck pain: results from the international collaboration on neck pain (ICON) project. Open Orthop. J. 7 (1), 494-505. https://doi.org/10.2174/1874325001307010494.
Walton, D.M., MacDermid, J.C., Giorgianni, A.A., Mascarenhas, J.C., West, S.C., Zammit, C.A., 2013. Risk factors for persistent problems following acute whiplash injury: update of a systematic review and meta-analysis. J. Orthop. Sport. Phys. Ther. 43 (2), 31-43. https://doi.org/10.2519/jospt.2013.4507.

Wertli, M.M., Rasmussen-Barr, E., Weiser, S., Bachmann, L.M., Brunner, F., 2014a. The role of fear avoidance beliefs as a prognostic factor for outcome in patients with nonspecific low back pain: a systematic review. Spine J. 14 (5), 816-836. https://doi. org/10.1016/j.spinee.2013.09.036.

Wertli, M.M., Eugster, R., Held, U., Steurer, J., Kofmehl, R., Weiser, S., 2014b. Catastrophizing - a prognostic factor for outcome in patients with low back pain: a systematic review. Spine J. 14 (11), 2639-2657. https://doi.org/10.1016/j.spinee. 2014.03.003.

Wingbermühle, R.W., van Trijffel, E., Nelissen, P.M., Koes, B., Verhagen, A.P., 2018. Few promising multivariable prognostic models exist for recovery of people with nonspecific neck pain in musculoskeletal primary care: a systematic review. J. Physiother. 64 (1), 16-23. https://doi.org/10.1016/j.jphys.2017.11.013.

Wirth, B., Humphreys, B.K., Peterson, C., 2016. Importance of psychological factors for the recovery from a first episode of acute non-specific neck pain - a longitudinal observational study. Chiropr. Man. Ther. 24 (9). https://doi.org/10.1186/s12998 016-0090-2. 